Review

\title{
Epithelial-Mesenchymal Transition (EMT) and Regulation of EMT Factors by Steroid Nuclear Receptors in Breast Cancer: A Review and in Silico Investigation
}

\author{
Ioannis A. Voutsadakis ${ }^{1,2}$ \\ Received: 8 December 2015; Accepted: 30 December 2015; Published: 19 January 2016 \\ Academic Editors: David A. Brenner, Tatiana Kisseleva and Jonas Fuxe \\ 1 Division of Medical Oncology, Department of Internal Medicine, Sault Area Hospital, \\ Sault Ste Marie, ON P6B 0A8, Canada; ivoutsadakis@yahoo.com or ivoutsadakis@nosm.ca; \\ Tel.: +1-705-759-3434 \\ 2 Division of Clinical Sciences, Northern Ontario School of Medicine, Sudbury, QC P3E 2C6, Canada
}

\begin{abstract}
Steroid Nuclear Receptors (SNRs) are transcription factors of the nuclear receptor super-family. Estrogen Receptor $(\mathrm{ER} \alpha)$ is the best-studied and has a seminal role in the clinic both as a prognostic marker but also as a predictor of response to anti-estrogenic therapies. Progesterone Receptor (PR) is also used in the clinic but with a more debatable prognostic role and the role of the four other SNRs, ER $\beta$, Androgen Receptor (AR), Glucocorticoid Receptor (GR) and Mineralocorticoid Receptor (MR), is starting only to be appreciated. ER $\alpha$, but also to a certain degree the other SNRs, have been reported to be involved in virtually every cancer-enabling process, both promoting and impeding carcinogenesis. Epithelial-Mesenchymal Transition (EMT) and the reverse Mesenchymal Epithelial Transition (MET) are such carcinogenesis-enabling processes with important roles in invasion and metastasis initiation but also establishment of tumor in the metastatic site. EMT is governed by several signal transduction pathways culminating in core transcription factors of the process, such as Snail, Slug, ZEB1 and ZEB2, and Twist, among others. This paper will discuss direct regulation of these core transcription factors by SNRs in breast cancer. Interrogation of publicly available databases for binding sites of SNRs on promoters of core EMT factors will also be included in an attempt to fill gaps where other experimental data are not available.
\end{abstract}

Keywords: Steroid Nuclear Receptors; Epithelial Mesenchymal Transition; Mesenchymal Epithelial Transition; ER $\alpha$; PR; AR; ER $\beta$; GR; MR; breast cancer

\section{Introduction}

Breast cancer is the most common cancer in women and a majority of cases (about three-fourths) express the Estrogen Receptor $(E R \alpha)$. Most of these cancers co-express different degrees of the Progesterone Receptor (PR) and the Androgen Receptor (AR). Some of the ER-negative breast cancers express the AR and constitute a special category of those ER-negative cancers which have commonly apocrine features on pathologic examination [1]. All three receptors, together with Glucocorticoid Receptor (GR), Mineralocorticoid Receptor (MR) and a second nuclear receptor for estrogens termed $\mathrm{ER} \beta$, comprise the steroid receptor sub-family of nuclear transcription factors. They display a common protein structure with conserved domains, not only within the steroid receptor sub-family but also with non-steroid receptors [2]. These domains include an amino-terminal activation domain (Activation Function 1, AF-1), a DNA-binding domain, a hinge region and a carboxy-terminal ligand-binding domain [3]. Response sequences on target gene promoters have similarities amongst 
the Steroid Nuclear Receptors (SNRs) [4]. The various SNRs regulate different sets of genes due to additional factors such as the availability of their ligands, their own expression and post-translational modifications that regulate their transcriptional activity and the availability of co-regulators such as co-activators, co-repressors and pioneer factors that shape the overall effect of each SNR on the whole genome scale in a particular cell by modifying the chromatin landscape and the ability of SNRs to interact with it [5-7].

The roles of Epithelial to Mesenchymal Transition (EMT) and the reverse Mesenchymal to Epithelial Transition (MET) processes as central enabling capabilities in cancer invasion and metastasis have been confirmed over the last several years and involve the activity of a core set of transcription factors (TFs) activated by signal transduction pathways in neoplastic cells [8,9]. The following sections will discuss available evidence of direct regulation of transcription of EMT core transcription factor genes by SNRs in breast cancer. Indirect regulations are also important but will not be considered in detail in this overview, except in situations where their discussion will elucidate the discussion of direct regulations. A further inquiry through publicly available promoter databases will be reported on direct regulations where other experimental data are lacking in order to guide future investigations.

\section{Epithelial to Mesenchymal Transition (EMT) and Mesenchymal to Epithelial Transition (MET) in Breast Cancer}

EMT is a process that physiologically takes place during normal embryonic development and in adult tissue injury repair. In contrast to these two physiologic conditions where EMT serves normal functions, cancer is a pathologic condition where EMT occurs [8]. During EMT in cancer, transformed epithelial cells lose epithelial membrane adhesions, invade through the epithelium basement membrane and acquire the ability to move on freely in neighboring tissue or to metastasize to distant organs using vascular routes. Cells undergoing EMT, in addition to losing inter-cellular junctions, lose epithelial cell polarity, gain a fibroblast-like shape, down-regulate epithelial markers such as E-cadherin, claudins, occludins and cytokeratins, and up-regulate mesenchymal markers such as S100A4 (also called FSP1(Fibroblast-Specific Protein 1)), vimentin and cadherin N [10].

EMT occurring in cancer may be incomplete both in the individual cell and the cell population level and only part of the EMT markers may be expressed in small sub-sets of cancer cells [11]. Incomplete EMT, as, for example, seen during the process of collective migration, allows cells to detach from the epithelial site, acquire some mesenchymal features, but still move as small groups of few cells without losing adhesions between the members of the group [11]. Further witness of the role of EMT as intrinsic to the malignant process is borne by the discovery that beyond specific EMT-inducing factors, such as the core EMT transcription factors Snail and Slug, a multitude of general cancer-regulating pathways are important EMT regulators [9]. Examples specifically pertinent to breast cancer include Her2/Neu receptor-activated pathways as well as ER and PR receptors, discussed in subsequent sections. Due to the incompleteness of the EMT process in cancer, neoplastic cells may more readily revert back to an epithelial state through the reverse process of Mesenchymal to Epithelial Transition (MET), which participates in metastasis establishment in remote organs [12]. The EMT circuitry in transformed cells closely co-operates with the pluripotency network of cancer stem cells in order to obtain the required plasticity for alternating epithelial and mesenchymal states [13].

Several pathways activated in cancer have the ability to activate a set of core EMT transcription regulators which eventually lead to E-cadherin down-regulation and cell-cell adhesion dissolution. EMT core factors include Snail1 and Snail2 (also called Slug), ZEB1 (also known as TCF8 or 8EF1) and ZEB2 (also known as SIP1 or Zfhx16), Twist, FoxC2, TCF3 (also known as E47 or E2A), Goosecoid homeobox (also called SAMS) and LBX1.

Although overlapping, the genomic effects of different EMT factors are distinct [14]. In breast cancer, the expression of EMT core factors supports different phases of EMT. For example, involvement of Snail1 appears to be instrumental in the initiation of the process while Twist1 becomes essential later during EMT establishment [15]. ZEB proteins are additional factors required for EMT maintenance [16]. 
Most information on EMT transcription in breast cancer refers to the triple-negative basal-like sub-type associated with BRCA1 mutations which increase Slug protein stability [17] but data on ER-positive cancers are also available.

\section{SNRs and EMT in Breast Cancer}

SNRs constitute a sub-family of the nuclear receptor family which has 48 members in humans [4]. The sub-family has six members with differing importance in breast cancer. While ER $\alpha$ is unarguably the most extensively studied protein in the disease and has the distinction of being the first successfully targeted by a treatment protein with the introduction of tamoxifen 40 years ago, PR and AR also have recognized but more controversial roles. ER $\beta$ has the peculiarity that, despite being a target of treatment, given that current hormonal therapies inhibit its activity in parallel with the activity of $\mathrm{ER} \alpha$, it is not currently evaluated clinically as a response marker. GR and, even more, MR, although not completely ignored, have hardly obtained the attention of the other NRs and their clinical role as contributors to pathogenesis of the disease or targets to therapy is less well-defined [18]. All six SNRs bind DNA as dimers and the binding sequences (Response Elements, REs) on the promoters are similar [4]. ER $\alpha$ consensus RE (ERE) consists of two tandem examers with the sequence 5'-AGGTCA-3' in an inverted repeat configuration divided by a spacer of three nucleotides (IR3). ER $\beta$ has a similar binding sequence to ER $\alpha$ but the second examer requirements are less strict in certain positions. The four other NRs use also IR3 configuration in their binding but their recognized examer is different from ER in the third and fourth nucleotides and consists of the sequence 5'-AGAACA-3'. In addition, AR and PR may use a direct repeat configuration with a three-nucleotide spacer (DR3) as an alternative to IR3 [19]. Although the presence of a binding site of a SNR is important for the regulation of a target gene, it has to be recognized that a regulation may be indirect through a different transcription factor whose expression is regulated by the SNR. Alternatively, there are occasions where SNRs regulate their targets by being tethered to another transcription factor such as AP-1 or Sp1 [20,21]. Moreover, the presence of a RE is not always sufficient for a regulation to occur, as additional prerequisites have to be fulfilled such as expression of the SNR itself in a given breast cancer cell and a permissive open chromatin configuration obtained at least partially through binding of pioneer factors that guide SNRs to sub-sets of their targets [22].

\section{1. $E R \alpha$}

ER $\alpha$ is expressed in the majority (about three-fourths) of breast cancers. The degree of expression, though, varies significantly both between different patients with ER-positive disease and in different cells of the same cancer. Currently, all breast cancer patients with ER expression in more than $1 \%$ of their cancer cells are treated as ER-positive and hormonal manipulations are included in their adjuvant treatment schedules. An example of differential expression of ER in cells of the same breast cancer is provided by the presence of ER-negative stem cells in ER-positive cancers which mimics the normal epithelial breast tissue hierarchy [23-25]. Experiments using human embryonic stem cells expressing ER $\alpha$ and cultured in the presence of estrogens in vitro have confirmed that ER $\alpha$ activity is associated with differentiation and promotes the epithelial phenotype [26]. As it will be discussed in next sections, this is due in part to direct suppression of core EMT factors. In addition, $\mathrm{ER} \alpha$ suppresses EMT through suppression of EMT, promoting signalling transduction cascades such as TGF $\beta$ and NF-KB [27]. Knock-down of ER $\alpha$ by siRNA or by lentiviral-transfected shRNA in $\mathrm{ER} \alpha$-positive breast cancer cells leads to EMT and increased migration and invasion [28,29]. The effect of estrogen-activated ER $\alpha$ on TGF $\beta$ signalling down-regulation is mediated by binding to Smad 2 and Smad3 and promoting their proteasome degradation [30]. This would impede the growth-inhibiting and EMT-promoting effects of the TGF $\beta$ cascade and favour the epithelial phenotype but also accelerate cancer cell growth, both known effects of ER $\alpha$ signalling in breast cancer (Figure 1). Changes in TGF $\beta$ signalling between normal and cancerous ER-positive cells have been proposed to explain differences in their proliferation status [31] but may also explain the EMT suppressing effect of ER $\alpha$ 
in ER-positive cancers. On the other hand, there is an inverse correlation of ER $\alpha$ expression and NF- $\mathrm{kB}$ sub-unit RelB expression in breast cancer cell lines and human breast cancer samples [32] (Figure 1). Suppression of ER $\alpha$ in ER-positive MCF7 cells by siRNA leads to up-regulation of RelB and the increased expression is associated with a mesenchymal phenotype, vimentin induction, E-cadherin suppression and increased migration in matrigel assay [32]. Interestingly, the same group has reported a reciprocal regulation whence RelB represses ER $\alpha$ expression [33]. Both Snail1 and ZEB1, which are activated in breast stem-like cells, suppress ER expression [34,35] and in the case of Snail1, NF- $\mathrm{KB}$ signalling is involved [35]. Another pathway through which ER $\alpha$ suppresses EMT involves up-regulation of protein MTA3 (Metastatic Tumor Antigen 3) which is a suppressor of Snail and other EMT proteins [36].

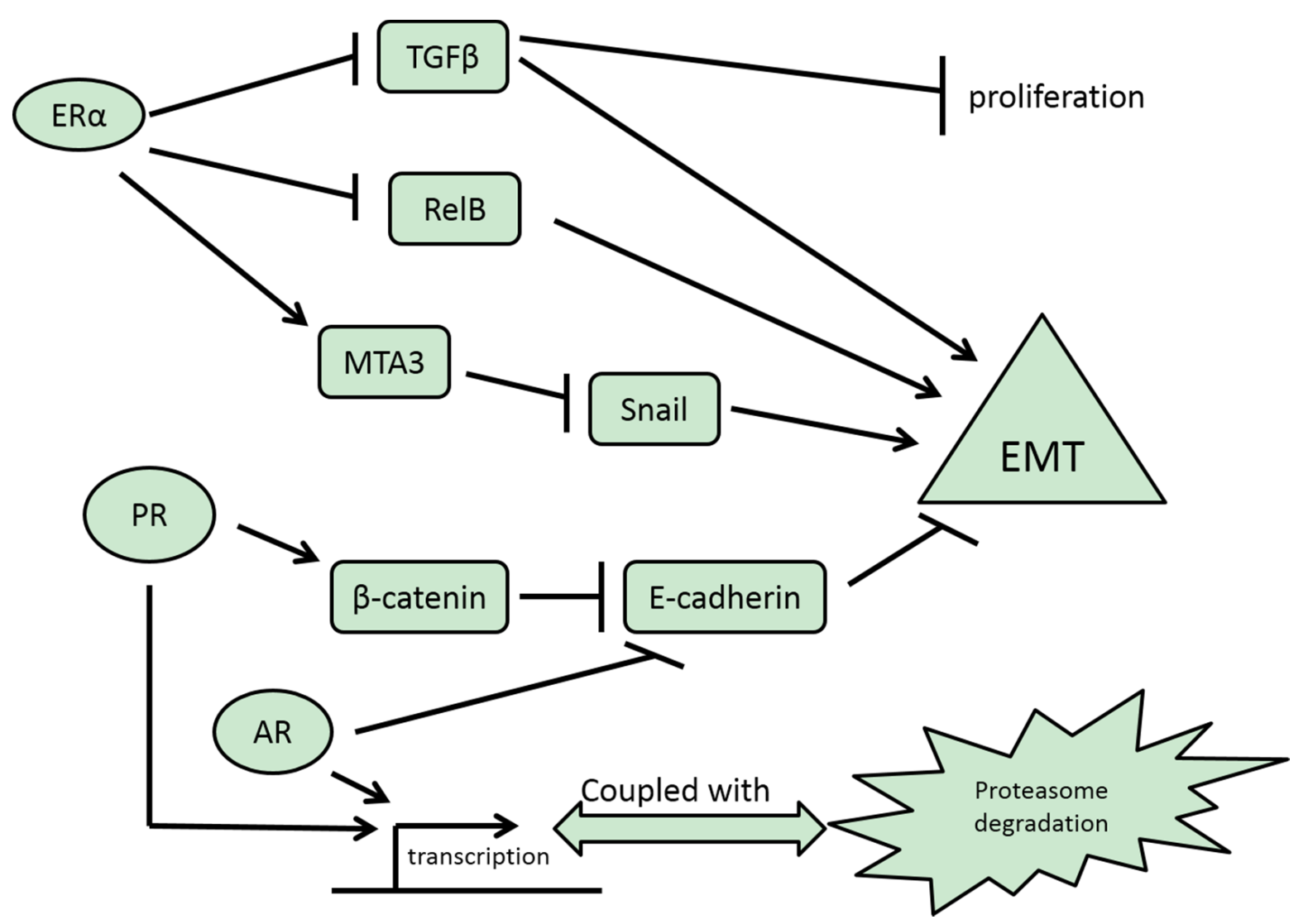

Figure 1. Pathways leading to EMT regulation by SNRs ER $\alpha$, PR and AR. Transcriptional activity affecting EMT may be coupled with proteasome recycling, and thus the relationship of EMT regulation and receptor expression may not be straightforward. Arrows denote activation and reverse T signs denote inhibition.

\section{2. $E R \beta$}

ER $\beta$ is transcribed from a gene at human chromosome locus $14 \mathrm{q} 23$, a different chromosomal location from the ER $\alpha$ gene which is situated at chromosome 6q25 [37]. ER $\beta$ is the main receptor expressed in normal mammary epithelium [38]. The two SNRs have very high homology $(96 \%)$ in their DNA-binding domain and significant homology also in their ligand-binding domain [39]. Thus, they bind natural agonists and drug antagonists with similar affinity. Nevertheless, and despite their high homology, their binding sequence requirements are slightly different, as mentioned. In breast cancer, there is a high correlation of ER $\alpha$ and ER $\beta$ expression and most ER $\alpha$-positive cancers (55\% of the total number of breast cancers) also express ER $\beta$ (Figure 2). The remaining $\mathrm{ER} \alpha$-positive breast cancers (about 15\% of total breast cancers) are ER $\beta$-negative. The ER $\alpha$-negative 
breast cancers are equally divided between ER $\beta$-positive and ER $\beta$-negative. In ER $\alpha$-positive cancers, $\mathrm{ER} \beta$ has a modulating activity, acting as dominant negative regulator and reducing ER $\alpha$-dependent transcription [37]. Another immunohistochemical study found only half of luminal cancers to express ER $\beta$, and that was true also for about $40 \%$ of basal-like carcinomas [40]. In this study ER $\beta$ was a negative prognostic factor for overall survival. Still another study affirmed a somewhat lower ER $\beta$ positivity in $33 \%$ and $25 \%$ of ER $\alpha$-positive and -negative breast cancers, respectively [41]. In the cohort with ER $\alpha$-positive cancers that received tamoxifen treatment, ER $\beta$ expression was associated with an improved recurrence-free survival. In vitro studies confirmed that treatment of ER $\alpha$-positive breast cancer cell lines with ER inhibitors produced an enhanced inhibitory effect when ER $\beta$ was co-expressed [41]. In contrast, ER $\alpha$-negative cell lines with ER $\beta$ expression were not inhibited by ER inhibitors but were inhibited by ER $\beta$-specific agonists (Figure 3). In the same vein, genomic studies have shown that the transcriptomes of the two ER receptors overlap significantly but can be modified by the each other's presence [42]. Importantly for EMT, in MCF7 breast cancer cells transduced with the receptor, ER $\beta$ regulates many components of the TGF $\beta$ pathways, resulting in suppression of the TGF $\beta$ cascade and up-regulation of the BMP cascade through up-regulation of BMP7 [42]. Overall, these effects result in EMT suppression. A similar genomic study that used another breast cancer cell line, T47D, confirmed only a partial overlap of the two ER receptors transcriptomes but failed to confirm the extensive role of ER $\beta$ transcription on TGF $\beta$ signalling [43]. Experimental differences notwithstanding, these results may pinpoint the importance of the specific cellular environment for specific gene regulation. The above data of ER $\beta$ expression in normal mammary glands as well as the inhibitory effects observed with its activation in the absence of ER $\alpha$ and the suppression of the TGF $\beta$ pathway that it mediates argue for a negative effect of ER $\beta$ for EMT and a tumor-suppressor and anti-metastatic role in breast cancer. In ER $\alpha$-positive cancers, the presence of ER $\beta$ may, at least in certain occasions, act as an EMT promoter by interfering with ER $\alpha$ activity, but, on the other hand, due to this interference with ER $\alpha$ activity, ER $\beta$ may sensitize to hormone-blocking agents by setting ER $\alpha$ activity to a lower level that would be more easy to inhibit.
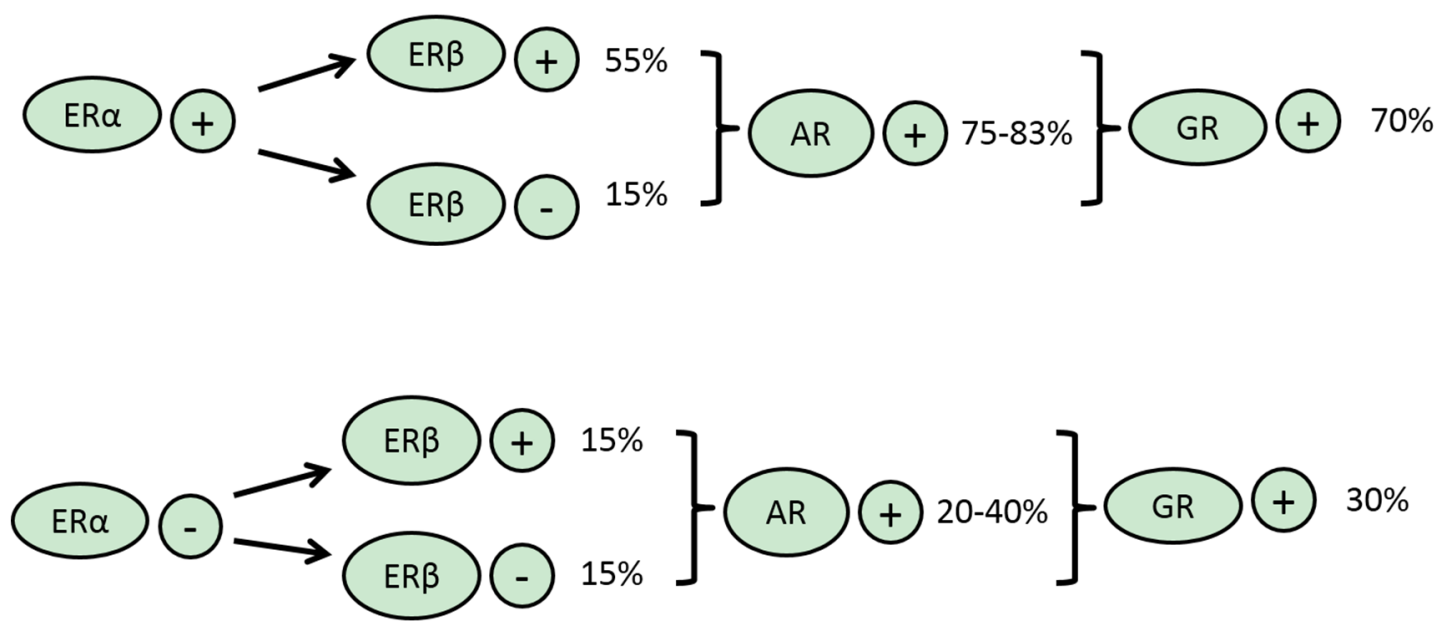

Figure 2. Expressions of other SNRs in ER $\alpha$-positive and ER $\alpha$-negative breast cancers. 

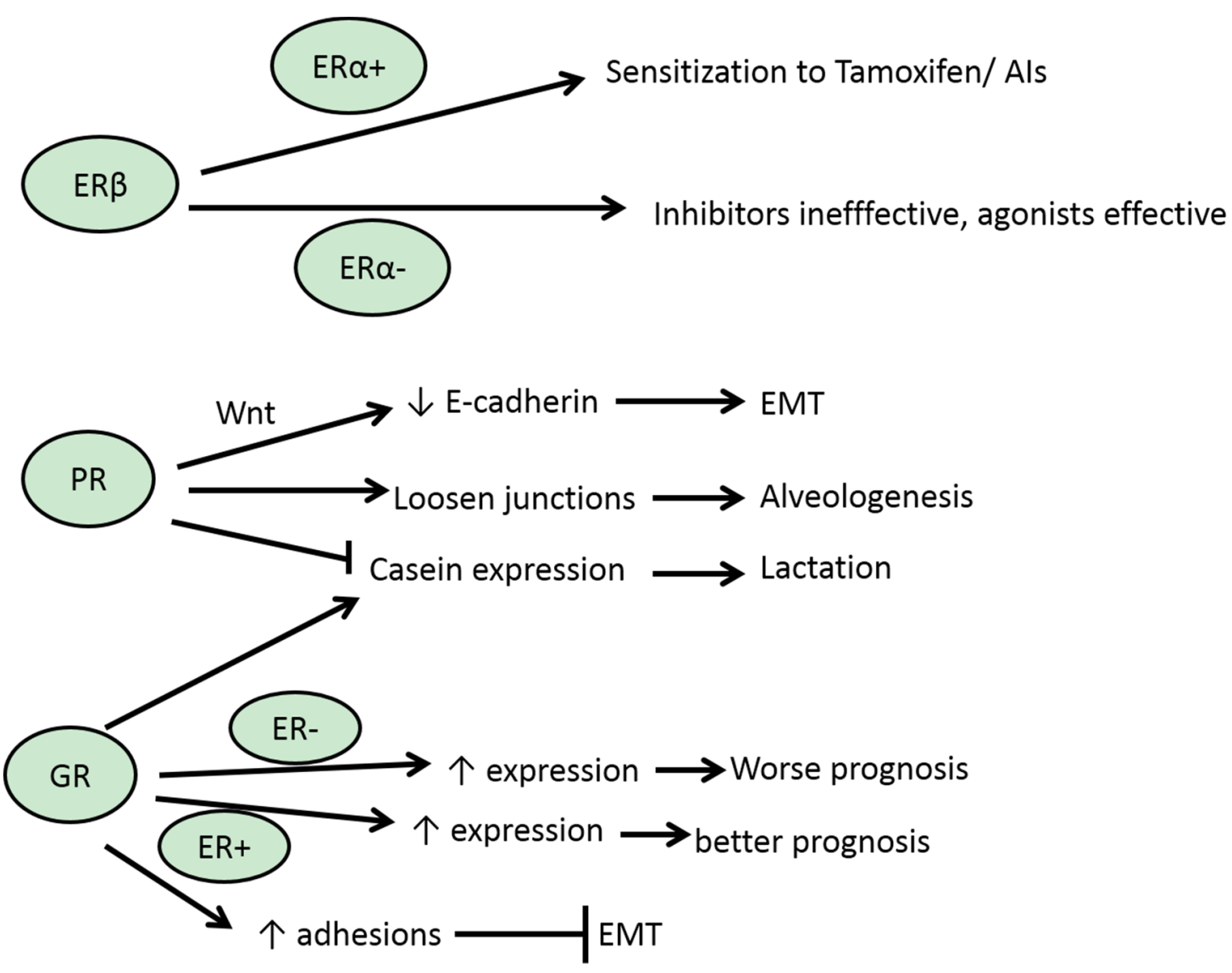

Figure 3. A schematic representation of selected EMT-related effects of ER $\beta, P R$ and GR in normal breast development and breast cancer and relationships with ER $\alpha$ status.

\section{3. $P R$}

PR expression is observed mainly in ER-positive breast cancers [44]. There is some controversy about the role of PR in breast cancer, given that progesterone is pro-proliferative in the normal breast and hormone replacement therapy which includes progestagens in addition to estrogens increases the risk of breast cancer in postmenopausal women [45]. Despite this controversy, most data agree that ER-positive/ PR-negative or low breast cancers align with the genomic luminal B sub-type and are associated with inferior clinical outcomes compared with luminal A cancers with high PR expression [46]. Part of the controversy regarding the role of PR in established breast cancer stems also from the fact that PR expression does not completely correlate with its activity and indeed it was proposed that the most transcriptionally active form of PR is unstable due to fast proteasome degradation and would not be captured by standard immunohistochemistry [47] (Figure 1). Besides being a marker of ER transcriptional activity as a target gene of ER, PR may also have profound effects on the ER transcriptome by decreasing the availability of transcription factor AP1, an ER co-factor, by inducing phosphatase MKP-1 (MAPK Phosphatase 1, also known as DUSP1), an inhibitor of the MAPK cascade that activates AP-1 [48]. In addition, this constitutes a negative feedback loop because MAPK positively affects PR transcriptional activity by phosphorylating the receptor at serine 294 residue [49].

A physiologic role of PR in normal mammary glands during pregnancy and lactation in mice is mediated by junctional effects [50]. During pregnancy, high progesterone levels lead to increased PR activity that contributes to suppression of differentiation towards a lactation-capable epithelial specialized cell by suppressing production of milk proteins such as casein (Figure 3). In addition, PR activity helps keep tight junctions between mammary cells loose, a fact that facilitates motility during remodelling of the gland. After parturition, the precipitous drop of circulating progesterone 
levels leads to both induction of lactation and closure of the tight junctions to allow milk to accumulate in the ducts [51]. Several components of cascades involved in EMT, such as Wnt4 of the Wnt/ $\beta$-catenin cascade, RANKL, a ligand of the NF- $\mathrm{kB}$ cascade and Id4, involved in regulation of EMT factor TCF3/E47, are induced by PR, contributing to the physiologic role of PR during mammary alveologenesis [52-54]. These physiologic PR effects may be usurped during EMT of cancer to promote loss of tight junctions and to enable motility and metastasis of transformed cells.

Suppression of E-cadherin and induction of EMT was reported to be mediated by activation of the B isoform of PR (PR-B) in vivo in rat mammary tumors and in vitro in human cell lines [55]. PR-B is the main isoform in normal mammary development, while PR-A, transcribed from the same gene but from an alternative promoter, lacks the 165 aminoterminal amino acids and acts as a PR-B repressor [56]. Nevertheless, suppression of E-cadherin by PR-B was an indirect effect through activation of the Wnt- $\beta$-catenin pathway, a well-known E-cadherin regulator. In contrast, activation of PR with synthetic progestin promesterone had no effect on induction of EMT core factors Snail and ZEB1 [55].

Overall, PR expression and activity favours junctional resolution and EMT. The apparent positive prognostic influence of PR expression in ER-positive cancers may be due to robust ER activity in these cancers, implied by the fact that PR is an ER target gene, and in addition, by the fact that strong PR expression, as detected by immunohistochemistry, may denote, counter-intuitively, a less transcriptionally active protein, given that transcriptional activity is coupled with proteasomal degradation.

\section{4. $A R$}

AR is expressed in a sub-set of ER-negative breast cancers but also in an even more significant proportion of ER-positive cancers. In a series of triple-negative breast cancers, using a cut-off of $10 \%$ to determine AR positivity, it was shown that about $20 \%$ of patient tumors were positive for AR [57]. In contrast, another series showed a higher (40\%) positivity of AR in triple-negative tumors [58]. A similar percentage was seen in another study which also confirmed that ER-positive cancers had a much higher AR positivity at 83\% [59] (Figure 2). A meta-analysis of 19 studies that included 7693 patients showed $74.8 \%$ of ER-positive patients to be concomitantly AR-positive while $31.8 \%$ of ER-negative patients were AR-positive [60]. In addition, AR expression was a good prognostic marker irrespective of ER expression.

AR activation by dihydrotestosterone treatment in breast cancer cells has been reported to directly suppress the E-cadherin promoter in an artificial transfection system in breast cancer cell lines and favour metastatic spread in vivo in mice [61]. ER-positive cell lines with epithelial morphology displayed a mesenchymal morphology when transfected with AR and treated with dihydrotestosterone. In addition, a binding site for AR was characterized in the E-cadherin gene promoter (Figure 1). Thus, AR may have EMT-promoting effects through this suppression and even independently of any effects on EMT core transcription factors. These results are in contrast with the above-discussed absence of direct induction of E-cadherin by PR, despite the similar binding sequence requirements of the two steroid receptors, and speak again for the importance of the many additional factors regulating transcription initiation that are required in order for transcription to proceed. In addition, even subtle deviations in certain nucleotide sites of binding sequences may affect the binding of one receptor to a specific promoter more than the binding of another [19].

Interestingly, there was no correlation of AR with E-cadherin expression or DFS (Disease-Free Survival) in the aforementioned study of triple-negative cancers [57]. In addition, the fact that AR expression is associated with a good prognosis in all sub-types of breast cancer may imply that it has tumor-suppressing and thus anti-metastatic and EMT-suppressing effects. Nevertheless, as evidenced from the case of ER which has tumor-promoting effects, despite its expression in less aggressive breast cancers and EMT-suppressing activity, this may not be entirely correct. Moreover, AR transcription is 
associated with turnover of the receptor in the proteasome, similarly to PR activity [62]. Thus, a higher expression by immunohistochemistry may imply higher stability due to lower transcriptional activity.

\subsection{GR}

GR displays both anti-proliferative and anti-apoptotic effects in mammary cancer and pre-cancerous cells $[63,64]$. GR expression is seen in about $60 \%$ of breast cancers and appears to be associated with ER expression with about $70 \%$ of ER-positive tumors expressing GR compared with only about $30 \%$ of ER-negative tumors [65] (Figure 2). A gradual decrease of GR expression from normal breast tissue to in situ carcinoma to invasive carcinoma has been described [66,67]. GR is able to bind to ER promoter sites in a manner facilitated by FoxA1 and AP1, and displace ER and repress promoter activity [68,69]. These effects are dependent on both ER and GR receptor ligation and may have important implications for glucocorticoid influence on the global ER program and also specifically on EMT in ER-positive cancers. A mutual modulation of ER and GR DNA binding has been confirmed in another genomic study which also confirmed a role for AP1 in these interplays [70]. Regarding ER-negative carcinomas, functional disabling of GR signalling is evident in tumors with BRCA gene mutations or BRCA dysfunction [71]. BRCA1 has a role in the suppression of Twist and its silencing leads to Twist de-repression and EMT [72]. In addition, BRCA1 is a post-translational suppressor of Slug [73]. Thus, EMT promotion in triple-negative basal-like breast cancer cells that have BRCA1 dysfunction may be independent of GR. Nevertheless, EMT was also identified as one of the primary processes regulated by GR in a ChIP-seq study of ER-negative MCF10A breast cancer cells immortalized by c-myc transfection [74]. Interestingly, meta-analysis of data from publicly available, clinically annotated transcriptome studies showed that the prognostic information of GR expression was discordant between ER-positive and -negative patients. In ER-negative patients higher GR expression conferred a worse prognosis while in ER-positive patients the reverse was true [74] (Figure 3).

During lactation GR co-operates with prolactin-induced transcription factor Stat5 to induce transcription from the casein promoter [75]. In this respect GR is antagonistic to the action of PR which, as mentioned above, suppresses lactation (Figure 3). Whether this is true for other actions of PR, such as its effects on intercellular junctions that affect cell motility, remains to be confirmed. A study with MDA-MB-231 breast cancer cells that are ER- and PR-negative but GR-positive suggests that this may be the case in some cellular environments as treatment with corticosteroids leads to an increase in focal adhesions and a cobblestone-like morphology, implying a MET effect in this setting [76]. This is also in contrast to what was shown in MCF10A cells as discussed above, but argues again for the importance of cellular context. MDA-MB-231 cells line belongs to a sub-set of triple-negative breast cancer cell lines that have been genomically characterised as mesenchymal as opposed to other triple-negative cell lines, such as MDA-MB-468, which are characterised as basal-like [77]. These latter cell lines have been reported to be less sensitive to GR inhibition, possibly due to the functional disabling of the steroid receptor occurring with BRCA1 dysfunction [78]. These studies suggest that GR may have divergent effects depending on ER expression in breast cancer. An additional important result to derive from these data is that promotion of EMT or MET by a transcription factor in a specific setting is not directly related to better or worse prognosis, respectively, but could rather be associated more with facilitation by the factor in question of the passage of a malignant cell from one state to the other in order to be able to metastasize and establish itself in the metastatic site [79].

\section{6. $M R$}

MR has overlapping effects with PR and GR in breast cancer and can substitute for GR during mammary development $[76,80]$. Thus, it is expected that it may modulate EMT, although this has not been specifically studied. In kidney epithelial cells, where its main physiologic role resides, stimulation of MR with aldosterone has been implicated in promotion of fibrosis, a hallmark of EMT in tissue injury [81]. Down-regulation of E-cadherin and up-regulation of Smooth Muscle Actin (SMA) were 
observed after ligand aldosterone exposure in human proximal tubule cells [82], but whether a similar regulation occurs in the breast has not been studied. This would be opposite to the GR effect despite their similar DNA target sequences and reinforces the fact that extrapolations to different cellular contexts are not justified given the high influence of these contexts for the final outcome of a nuclear receptor's actions.

From these data it becomes apparent that SNRs have regulatory roles in EMT and affect the process both positively and negatively with implications for the promotion of the reverse MET process as well. The role of ER $\alpha$ in EMT suppression is mediated by both indirect mechanisms but also direct effects on promoters of core EMT factors which will be discussed in subsequent sections. Among the other SNRs, effects are divergent depending on ER $\alpha$ expression.

\section{Snail1 and Slug and Regulation by SNRs}

Snail1 and Slug (Snail2) are zinc finger-containing transcription factors of the $\mathrm{C} 2 \mathrm{H} 2$ type that promote EMT by suppressing expression of E-cadherin and other adhesion molecules. Both proteins bind E-box sequences with the consensus $5^{\prime}$-CANNTG-3' in the promoter of the E-cadherin gene with their zinc fingers [83]. Snail1 is a more potent E-cadherin suppressor. Both Snail proteins as well as TCF3 are expressed in the branching sites during normal mammary morphogenesis and are necessary and sufficient for induction of the process [84]. Snail1 and Slug protect cells in mammary tubules undergoing branching from apoptosis induced by p53 and BID [84]. Snail1 also protects non-transformed human mammary epithelial cells from anoikis [85]. Snail1 inhibition, on the other hand, correlates with down-regulation of RhoA, a GTPase that promotes motility [86]. Both Snail family members are expressed in breast cancer at the mRNA and protein level $[13,87,88]$.

Activation of ER $\alpha$ by estrogen ligation in breast cancer cell lines leads to direct repression of the Slug promoter as the liganded nuclear receptor attracts a repressor complex which includes histone deacetylase 1 and N-CoR (Nuclear Co-Repressor) but not SRC-3 (Steroid Receptor Coactivator 3) or IKK $\alpha$ in MCF7 breast cancer cells [89]. Three ER $\alpha$ half binding sites have been identified in the Slug promoter, but it remains unknown whether one or more of them is the actual required binding site. Of note, a search for full sites in the three human promoters of Slug listed in TRED (Transcriptional Regulatory Element Database, https://cb.utdallas.edu/cgi-bin/TRED/) did not disclose any ER $\alpha$-binding sequences. Slug suppression in ER $\alpha$-transfected breast cancer cells treated with estradiol up-regulates E-cadherin expression and decreases their invasiveness in an in vitro assay [90]. In contrast, when ER $\alpha$ was knocked down in cells initially expressing it, Slug was up-regulated and cell morphology was altered to a more fibroblast-like phenotype [90]. In addition to direct suppression, ER $\alpha$ suppresses Snail proteins indirectly through transcriptional repressor MTA3 in the case of Snail and through inactivation of GSK3 kinase in the case of Slug [90,91]. In this last study that showed Slug suppression by ER $\alpha$, Snail was activated, although this effect could not overrule Slug suppression which led to EMT promotion [90]. Moreover, in another study using a different breast cancer cell line T47D, ER $\alpha$ in co-operation with SRC-3 up-regulated Snail and suppressed E-cadherin [92]. Thus, ER $\alpha$ signalling may have divergent effects in Snail protein regulation, depending on the cellular context and co-activators present. It also has to be considered that Snail proteins are regulated by multiple factors and ER $\alpha$ is not their sole regulator. Multiple parallel regulations lead to clinical cases where high levels of Snails expression are observed in breast cancers with high ER $\alpha$ content [93]. This may additionally be due to the fact that expression of ER $\alpha$ is not always associated with functional transcriptional competence.

AR has a role in EMT induction in benign epithelial prostate hyperplasia cells and this effect appears to be mediated through TGF- $\beta$ signalling and Snail induction [94]. In prostate cancer cell lines expressing AR, treatment with androgens led to significant induction of Slug within $2 \mathrm{~h}$ of treatment, suggesting a direct up-regulation. This effect was not observed in AR-negative lines or after knock-down of AR with siRNA [95]. No experimental data are available to ascertain an effect of AR in Snail family regulation in breast cancer cells. In fact, studies have shown significant differences of 
the AR actions between breast and prostate cells and, thus, data from the prostate cannot be directly extrapolated to breast cancer [96].

An in silico investigation of the human Snail and Slug gene promoters listed in the TRED and EPD (Eukaryotic Promoter Database, www.epd.vital-it.ch) promoter databases was performed using the binding sequences listed in the JASPAR database. The database enlists binding logos for ER $\alpha, E R \beta$, AR and NR3C1 (GR). It does not list PR and MR, but their binding sites are similar to AR and GR, respectively, as discussed previously. This search disclosed several binding sites for ER $\beta$ and GR in promoters of both Snail family transcription factors (Table 1). As mentioned above, no full sites for $E R \alpha$ were identified in Slug promoters and only a single site was identified in Snail promoters (Table 1). AR has several putative binding sites in Slug promoters but only a few in Snail. Overall, these data would argue for ER $\beta$ and GR (and in the case of Slug, for AR) being putative, more important Snail and Slug regulators than $\mathrm{ER} \alpha$.

Table 1. Number of binding sites of Steroid Nuclear Receptors (SNRs) in the different promoters of EMT core transcription factors Snail, Slug and ZEB1 and ZEB2, listed in the TRED and EPD databases. Progesterone Receptor (PR) and Mineralocorticoid Receptor (MR) appear in parentheses in the Androgen Receptor (AR) and Glucocorticoid Receptor (GR) column headings, respectively, as they have the same binding sites. In the last column, the number of promoters with clusters (more than three) of binding sites for each SNR (ER $\alpha / E R \beta / A R / G R)$ is presented.

\begin{tabular}{|c|c|c|c|c|c|c|c|}
\hline Factor & Database & Promoter & $\mathbf{E R} \alpha$ & $\mathrm{ER} \beta$ & AR (PR) & GR (MR) & Clusters \\
\hline \multirow[t]{3}{*}{ Snail } & TRED & 1 & 0 & 3 & 2 & 4 & $0 / 3 / 0 / 2$ \\
\hline & & 2 & 1 & 7 & 1 & 3 & \\
\hline & & 3 & 0 & 3 & 1 & 2 & \\
\hline \multirow[t]{3}{*}{ Slug } & TRED & 1 & 0 & 7 & 4 & 4 & $0 / 2 / 2 / 3$ \\
\hline & & 2 & 0 & 6 & 5 & 4 & \\
\hline & & 3 & 0 & 0 & 2 & 7 & \\
\hline \multirow[t]{5}{*}{ ZEB1 } & TRED & 1 & 1 & 7 & 2 & 6 & $0 / 4 / 1 / / 5$ \\
\hline & & 2 & 0 & 4 & 3 & 8 & \\
\hline & & 3 & 1 & 7 & 2 & 6 & \\
\hline & EPD & 1 & 0 & 4 & 1 & 5 & \\
\hline & & 2 & 0 & 1 & 0 & 3 & \\
\hline \multirow[t]{5}{*}{ ZEB2 } & TRED & 1 & 0 & 2 & 2 & 4 & $0 / 1 / 3 / 4$ \\
\hline & & 2 & 0 & 2 & 3 & 3 & \\
\hline & & 3 & 0 & 3 & 4 & 7 & \\
\hline & EPD & 1 & 0 & 1 & 1 & 2 & \\
\hline & & 2 & 0 & 1 & 7 & 4 & \\
\hline
\end{tabular}

An additional investigation was performed using the Transcriptomine tool, a nuclear receptor target gene database, offered by Nuclear Receptor Signaling Atlas (NURSA) to interrogate publicly available data from microarray experiments (www.nursa.org). An interrogation of the database for target genes with expression increase or decrease by at least two-fold in human mammary tissues or cell lines disclosed regulations of several EMT core transcription factors in experiments using breast cancer cell lines and manipulations of $\mathrm{ER} \alpha$ and $\mathrm{ER} \beta$, but no experiments with the other SNRs were available. Results from this interrogation relevant to Snail and Slug are discussed in this section and in appropriate subsequent sections for each core factor wherever significant regulations were present. In MDA-MB-321 ER $\alpha$-negative cells transfected with ER $\alpha$, activation by estradiol treatment for 24 $\mathrm{h}$ led to Snail up-regulation over 11 times greater than compared with estradiol-untreated cells [97]. Given the exposure timing, this may represent an indirect regulation. Additional experiments were performed with the same cell line transfected with a mutant ER $\alpha$ that displays significantly decreased ability to bind EREs but an increased GRE binding. Activation of these mutant transfectants by estradiol exposure for 2 to $24 \mathrm{~h}$ led to an up-regulation of Slug consistently at all time points by 2- to 2.7-folds. In contrast, in MCF-7 cells that express endogenous ER $\alpha$, knock-down of the receptor 
led to up-regulation of Slug by 30-fold [28]. A smaller increase of Slug was observed when MCF-7 cells transfected with ER $\beta$ were treated with estradiol [42]. These data speak for a possible direct up-regulatory effect of GR for Slug (at least in an artificial transfection system) and a down-regulatory effect of ER $\alpha$ in ER $\alpha$-positive cells, partially antagonized when ER $\beta$ is present.

\section{ZEB1 and ZEB2 and miR200 Family}

ZEB1 and ZEB2 are zinc finger transcription regulators that contain a homeodomain flanked by two zinc finger domains. Similar to the two Snail proteins, they promote EMT by binding to DNA through E-boxes of target gene promoters such as E-cadherin [98]. Their function is inhibited by the miR-200 family of miRs which bind multiple sites on the 3'-UTRs of their mRNAs, leading to mRNA destruction, and promote the inverse process MET [99]. The miR-200 family consists of two clusters transcribed from two chromosomal loci. miR-200a, miR-200b and miR-429 genes are located in human chromosome locus 1 p36 while miR-200c and miR-141 genes are in chromosome 12p13 [100,101]. In addition to down-regulation of ZEB1 and ZEB2 mRNAs, they also have several other targets throughout the transcriptome and their action leads to a coordinated maintenance of the epithelial phenotype [102]. There exists a double-negative feedback loop, as ZEB1 binds E-boxes in miR-200 promoters and suppresses their transcription [103].

ZEB1 is induced by estrogens with kinetics consistent with a direct regulation of transcription by $E R \alpha$ in various organisms and tissues $[104,105]$. Nevertheless, it was not induced by estrogens in human mammary cancer cell lines MCF7 and T47D [106]. Additionally, ZEB1 was not induced by estrogen treatment in OVCAR3 and Caov-3 ovarian cancer cell lines, but it was promptly induced after one hour in a different ovarian cancer cell line, OV266 [106]. These data support a cell-dependent ZEB1 regulation by estrogens even in the same cancer type. A study that examined miR200c expression in patients with breast cancer found no correlation of the expression of this miR-200 family miRNA with either ER or PR positivity [107]. A similar percentage of ER-positive and ER-negative patients were expressing high or low levels of miR-200c and the same was true of PR-positive and -negative patients [107]. In another study, though, the expression of miR-200 family mRNAs was decreased in clones of MCF7 cells resistant to the ER modulator tamoxifen and to ER down-regulator fulvestrant [108]. Parental cell line cells were sensitive to these agents and expressed a higher level of these miRs. Thus, an association of miR-200 expression with ER expression and function may be present in some cellular contexts, similarly to ZEB expression.

In a study employing breast cancer cell lines expressing one of the two isoforms of PR, either PR-A or PR-B, ZEB1 was found to be up-regulated specifically by PR-B [109]. This study used an artificial system with transfection of either of the two PR isoforms in a breast cancer cell line not expressing endogenous PR. ZEB1 was induced by 3.6 times when cells transfected by PR-B were treated with progesterone, while, as expected, no up-regulation was seen in cells transfected with PR-A, given that this isoform may not interact with DNA by itself.

ZEB1 is induced by AR in prostate cancer cells and in triple-negative breast cancer cells [110,111]. Similar to the induction by estrogens, there were discrepancies in different cellular environments in breast cancer, with a correlation of AR and ZEB1 expressions being evident in ER-negative but not in ER-positive cells [111]. A reciprocal regulation is present with ZEB1 inducing AR. Response elements of each transcription factor are present in the promoter of the other. Two Androgen Response Elements (AREs) in the ZEB1 promoter are both required for ZEB1 induction by androgens in an artificial promoter transfection system in prostate cancer cells [110]. In contrast, androgens do not induce ZEB1 in an AR-positive prostate cancer cell line. The authors of the study suggest that induction of ZEB1 is seen by androgens in studies employing exogenous promoter constructs because these constructs do not carry the $3^{\prime}$-tail used by miR-200 family members, while the endogenous mRNA species fail to show androgen-induced up-regulation because they are promptly degraded by miR-200s [110].

Evaluation of both ZEB1 and ZEB2 promoters from the TRED and the EPD databases reveals that ER $\beta, A R$ and GR have clusters of binding sites in ZEB1 or ZEB2 promoters and may be putative 
regulators. A single binding site of ER $\alpha$ is present in two ZEB1 promoters and no binding sites are present in ZEB2 promoters (Table 1). Transcriptomine data show up-regulation of both ZEB factors in MCF-7 cells with ER $\alpha$ knock-down [28]. This result, in combination with the discussed-above absence of ZEB induction observed in the same cell line [106], is most consistent with a model of ligand-independent suppressive ZEB promoter occupancy by ER $\alpha$.

\section{Twist}

Twist is a bHLH (basic Helix-Loop-Helix) transcription factor with a role in mammary development [83]. Twist molecules bind E-boxes in target gene promoters as dimers. Twist1 was detected in a small subset (1\%) of patients with breast cancer, in circulating tumor cells [112]. A study of the expression of Twist in breast cancer patients showed over-expression in about half of the patients [113]. A similar percentage of the patients in the study showed high expressions of Snail and Slug. An increased Twist1 expression is associated with decreased ER expression, down-regulation of aromatase enzyme and development of letrozole resistance in breast cancer cells [114]. This study did not address whether Twist targets ER for transcriptional down-regulation, but two other studies showed that, in fact, this is the case $[115,116]$. Twist1 associates with regulatory elements (E-boxes) on the ESR1 promoter and recruits the chromatin-suppressive apparatus. Histone acetylation and DNA methylation are incurred [115]. As a result, cell lines with high Twist expression were noted to be negative for ER by Western blotting, while the reverse was true for cell lines with low Twist expression. Of interest, promoter methylation is indeed a factor contributing to ER silencing in breast cancer patient specimens [117].

Regulation of ER by Twist may contribute to ER negativity of stem cells in ER-positive cancers and also to the presence of mesenchymal features in ER-negative cancers. The reverse regulation of Twist by ER or by other SNRs has not been reported. An in silico investigation of promoters of Twist listed in the TRED and EPD databases disclosed the presence of AR and GR sites but not sites of any of the two ERs (Table 2).

\section{TCF3 and Id Proteins}

TCF3, another bHLH transcription factor, is able to induce EMT in breast cancer cells by directly suppressing E-cadherin through binding to E-boxes of the promoter called E-pal and E3 [118]. The HLH factors of the Id family lacking a basic domain are inhibitors of TCF3 and modulate its effects on EMT creation. Despite this inhibition and the fact that TCF3 has been found to bind the E-cadherin promoter alone, Id proteins contribute to EMT maintenance in breast cancer and are expressed, together with $\mathrm{TCF} 3$, in human breast cancer samples, with a higher expression in the basal sub-type compared to the luminal sub-type [118]. Similarly, in another study using a different antibody, Id expression was noted in several metaplastic breast carcinomas but not in carcinomas with the "usual" morphology [119]. These data imply that an optimal level of TCF3 activity is required for maintenance of EMT and Id proteins participate in the regulation of this activity.

Association of TCF3 and Id family factors with the basal sub-type of breast cancers and their lower expression in luminal types may imply a down-regulation by ER and/or PR, but this has not been specifically reported. The investigation of promoters of TCF3 listed in the TRED database shows clusters of ER $\beta$, AR and GR binding sites (Table 2). 
Table 2. Number of binding sites of SNRs in the different promoters of Epithelial-Mesenchymal Transition (EMT) core transcription factors Twist, TCF3, FOXC2, Goosecoid and LBX1, listed in the TRED and EPD databases. PR and MR appear in parentheses in the AR and GR column headings, respectively, as they have the same binding sites. In the last column, the number of promoters with clusters (more than three binding sites) for each SNR is presented.

\begin{tabular}{cccccccc}
\hline Factor & Database & Promoter & ER $\alpha$ & ER $\beta$ & AR (PR) & GR (MR) & Clusters \\
\hline Twist & EPD & 1 & 0 & 0 & 2 & 2 & $0 / 0 / 0 / 0$ \\
TCF3 & TRED & 1 & 0 & 1 & 1 & 2 & $0 / 1 / 1 / 2$ \\
& & 2 & 1 & 3 & 0 & 6 & \\
FOXC2 & TRED & 1 & 0 & 1 & 3 & 1 & $0 / 1 / 1 / 1$ \\
& & 2 & 0 & 3 & 2 & 3 & \\
Goosecoid & EPD & 1 & 0 & 0 & 1 & 1 & $0 / 0 / 0 / 0$ \\
LBX1 & TRED & 1 & 0 & 2 & 4 & 1 & $0 / 1 / 3 / 2$ \\
& & 2 & 0 & 3 & 1 & 0 & \\
& & 3 & 0 & 2 & 3 & 3 & \\
\hline
\end{tabular}

\section{FoxC2}

FoxC2, a member of the Forkhead box family of transcription factors, is involved in EMT induction and the metastatic ability of breast cancer cells [120]. Signalling from the TGF $\beta$ cascade and the activity of transcription factors Snail, Twist and Goosecoid led to FoxC2 induction concomitantly with induction of EMT. Further experiments, to clarify the role of FoxC2 in EMT, showed that isolated FoxC2 induction in epithelial cells increased expression of mesenchymal markers such as vimentin and $\mathrm{N}$-cadherin but could not completely suppress epithelial proteins such as E-cadherin [121]. These results argue for a role of FoxC2 in mesenchymal phenotype maintenance after induction through other transcription factors. Interestingly, a genomic study has proposed a role of FoxC2 in the reverse MET process [121]. Cellular localization of the protein possibly plays a deciding role in the outcome, with cytoplasmic localization promoting epithelial traits by protecting E-cadherin from internalization while nuclear localization promotes EMT through transcription activity [122]. Insulin signalling, acting through the PI3K kinase, activates FoxC2 [123]. In breast cancer, PI3K is activated down-stream of Her2 and other signalling pathways and this may have implications for FoxC2 induction and EMT promotion. In contrast, when a serine at position 124 of FoxC2 is phosphorylated by Casein Kinase 2 (CK2), the transcription factor is retained in the cytoplasm and the epithelial phenotype is maintained [124]. The FoxC2 gene has been reported to have a higher expression in the claudin-low sub-type of triple-negative breast cancers compared with the basal sub-type and the luminal or Her2-overexpressing breast cancers [125].

No experimental data on FoxC2 regulation by SNRs have been reported. A search for binding sites shows clusters of ER $\beta$, AR and GR binding sites, but an absence of ER $\alpha$ binding sites in both the FoxC2 promoters listed in TRED (Table 2).

\section{Goosecoid}

Goosecoic (GSC) is a gene which encodes for a transcription factor that is highly expressed during embryonic development at the Spemann organizer, an area of the embryo where the establishment of body plan is initiated in gastrulation [126]. Both the Wnt/ $\beta$-catenin and the TGF $\beta$ signalling cascades are important in Goosecoid induction from distinct promoters during development [127]. TGF $\beta$ signalling is also important for Goosecoid induction in human adult breast epithelial cells [126]. Goosecoid mRNA is increased in micro-dissected breast cancer specimens compared with adjacent normal epithelium and the protein enhances tumor cell motility. Another cancer type where Goosecoid has been studied and been found to promote metastatic potential is hepatocellular carcinoma [128]. Part of Goosecoid contribution in EMT is mediated by induction of FoxC2 [129]. 
The influence of SNRs on Goosecoid regulation has not been explored in the literature. The single EPD promoter listed has one binding site for AR and one for GR but no clusters of SNR sites (Table 2).

\section{LBX1}

LBX1 (Ladybird homeobox 1) is a transcription factor whose gene is located in human chromosome 10q24. The mouse homolog participates in myogenesis and neurogenesis during development by promoting migration of dermomyotome precursors over long distances and the formation of skeletal muscles of the limbs [130]. Thus, a role of LBX1 has been sought in cancer metastasis. Indeed, in breast cancer, it has been found to be up-regulated compared with surrounding breast epithelium [131]. This is particularly evident in triple-negative cancers. LBX1 directly up-regulates ZEB1, ZEB2, Snail and TGFB2 but not Twist1 and promotes breast cancer cell migration, implying a role as a master regulator of EMT.

Although no further studies have been published so far regarding the role of LBX1 in breast cancer, its association with ER- and PR-negative cancers may hint at a regulation by steroid receptors. To investigate this possibility, a search for SNR binding sites in its four promoters listed in the TRED database was performed and it disclosed clusters of putative ER $\beta$, AR and GR sites but not any ER $\alpha$ sites (Table 2).

\section{Pioneer Factors}

Pioneer factors are proteins that bind compact chromatin to facilitate the binding of other transcription factors [132]. Several such factors that work to facilitate SNR DNA binding have been identified. These include FOXA1, AP2 $\gamma$, PBX1 and GATA3. FOXA1 is the best-studied and will be used as an example of how pioneer factors shape the landscape of SNRs in breast cancer and thus may modulate their influence on EMT. FoxA1 has been found to co-bind with ER $\alpha$ in about half of the target genes of ER $\alpha$ in a whole genome ChIP-on-chip study in breast cells [133]. Elevated FOXA1 expression is associated with a better prognosis and sensitivity to hormonal therapy in breast cancer patients [134]. FOXA1 is also a pioneer factor for AR DNA binding in prostate cancer cells and this function may be preserved in breast cancer expressing AR. An in vitro study confirmed this role of FoxA1 in ER-negative, AR-positive breast cancer cells [135]. FoxA1 guided AR binding to a sub-set of its binding sites and the silencing of FoxA1 abrogates this binding and negates the apocrine gene signature associated with AR in these cells. Consistently, in a clinical study of non-metastatic triple-negative breast cancers, co-expression of AR with FoxA1 defines a sub-group of patients with a distinct behavior reminiscent of luminal cancers [136]. In prostate cancer, FOXA1 carries reverse prognostic implications with high expression associated with hormone therapy resistance. As already mentioned, FOXA1 also acts as a pioneer factor for GR. As a result, the binding of pioneer factors may be a prerequisite for binding and transcription function of SNRs but may not be involved as a factor in the decision of which specific factor would be favored on the promoter of a specific gene. In contrast to SNRs and other TFs, pioneer factors may bind to remote sites up-stream of transcription initiation sites of target genes. For this reason, investigation of a possible role of these factors in the regulation of EMT core transcription factors should include longer sequences up-stream of transcription initiation sites. As a consequence, identification of pioneer factor binding sites regulating EMT transcription would require interrogation of several kilobases up-stream of initiation sites. Thus, an in silico investigation of EMT factors is not feasible through a promoter database interrogation. Of additional interest in a discussion of EMT, it should be noted that FoxA1 is a transcription activator of E-cadherin expression and could have influence on epithelial maintenance independent of SNRs [137].

\section{Perspective: EMT and Therapeutic Resistance Development and Reversal}

The significance of the EMT process in the pathogenesis of cancer, especially its involvement in the motility and metastasis of cancer in general and of breast cancer in particular, continues to be elucidated. Metastatic potential is an in-built capability of neoplastic cells and, in addition, it is 
intertwined with the network of pluripotency in breast and other cancers [13,138-140]. This association provides cancer cells with the plasticity required to switch from the epithelial state to the mesenchymal state during metastasis and then back to the epithelial state in the metastatic site. EMT is also associated with therapy resistance, which is a major hurdle in clinical oncology [141]. The implications of EMT for drug resistance were confirmed in a study of breast cancer in an in vivo transgenic mouse model where mice develop breast cancer with a short delay under the influence of a Her2 transgene [142]. Although cancer cells that had undergone EMT were not instrumental for metastatic establishment in this model, after cyclophosphamide treatment these EMT cells were more resistant to apoptosis and displayed an increased abundance in metastatic foci. In addition, cells with EMT features were less proliferative than other breast cancer cells. Decreased cycling is commonly a feature of stem cells which are also resistant to treatments and also commonly co-express EMT features [138]. These studies confirm the clinical importance of EMT in cancer progression, as resistant-to-chemotherapy (or other therapies such as hormonal treatments) clones represent the ultimate source of cancer treatment failures. Moreover, even at diagnosis, human cancer cells have already undergone selection through survival for several generations against adverse conditions and the host immune system. Thus, primary resistance may already be present, leading to first line treatment failure.

This review discusses the regulation of EMT by SNRs. Regulation by ER $\alpha$ is already exploited therapeutically in breast cancer, but several other steroid receptors present opportunities for therapeutic interventions. A more in-depth understanding of the influence of SNRs on EMT pathways and EMT core transcription factors which establish and maintain the transition and participate in feedback loops that reverse the cell to the epithelial state is a prerequisite to further advance therapeutic manipulations of these receptors in breast cancer. It would also offer the opportunity to introduce combinations of targeted interventions to interrupt EMT establishment based on specific molecular expression profiles. Given that approved medications in clinical use exist for all NSRs, receptor expression profiling in individual breast cancers together with knowledge of their regulation of EMT circuits may allow for a more informed targeted approach, leading to successful anti-metastatic treatment, with the additional advantage of not necessitating the cost and effort of new drug development.

Conflicts of Interest: The author declare no conflict of interest.

\section{References}

1. Le Du, F.; Eckhardt, B.L.; Lim, B.; Litton, J.K.; Moulder, S.; Meric-Bernstam, F.; Gonzalez-Angulo, A.M.; Ueno, N.T. Is the future of personalized therapy in triple-negative breast cancer based on molecular subtype? Oncotarget 2015, 6, 12890-12908. [PubMed]

2. Voutsadakis, I.A. Peroxisome proliferator activated receptor- $\gamma$ and the ubiquitin-proteasome system in colorectal cancer. World J. Gastrointest. Oncol. 2010, 2, 235-241. [CrossRef] [PubMed]

3. Anbalagan, M.; Huderson, B.; Murphy, L.; Rowan, B.G. Post-translational modifications of nuclear receptors and human disease. Nuclear Recept. Signal. 2012, 10, e001.

4. Helsen, C.; Claessens, F. Looking at nuclear receptors from a new ankle. Mol. Cell. Endocrinol. 2014, 382, 97-106. [CrossRef] [PubMed]

5. Beato, M.; Vicent, G.P. Impact of chromatin structure and dynamics on PR signaling. The initial steps in hormonal gene regulation. Mol. Cell. Endocrinol. 2012, 357, 37-42. [CrossRef] [PubMed]

6. Grøntved, L.; Hager, G.L. Impact of chromatin structure on PR signaling: Transition from local to global analysis. Mol. Cell. Endocrinol. 2012, 357, 30-36. [CrossRef] [PubMed]

7. Burd, C.J.; Archer, T.K. Chromatin architecture defines the glucocorticoid response. Mol. Cell. Endocrinol. 2013, 380, 25-31. [CrossRef] [PubMed]

8. Voutsadakis, I.A. The ubiquitin-proteasome system and signal transduction pathways regulating Epithelial Mesenchymal transition of cancer. J. Biomed. Sci. 2012, 19, 67. [CrossRef] [PubMed]

9. Voutsadakis, I.A. Ubiquitination and the Ubiquitin-Proteasome System as regulators of transcription and transcription factors in epithelial masenchymal transition of cancer. Tumour Biol. 2012, 33, 897-910. [CrossRef] [PubMed] 
10. Zeisberg, M.; Neilson, E.G. Biomarkers for epithelial-mesenchymal transitions. J. Clin. Investig. 2009, 119, 1429-1437. [CrossRef] [PubMed]

11. Micalizzi, D.S.; Farabaugh, S.M.; Ford, H.L. Epithelial-mesenchymal transition in cancer: Parallels between normal development and tumor progression. J. Mammary Gland Biol. Neoplasia 2010, 15, 117-134. [CrossRef] [PubMed]

12. Guo, F.; Parker Kerrigan, B.C.; Yang, D.; Hu, L.; Shmulevich, L.; Sood, A.K.; Xue, F.; Zhang, W. Post-transcriptional regulatory network of epithelial-to-mesenchymal and mesenchymal-to-epithelial transitions. J. Hematol. Oncol. 2014, 7, 19. [CrossRef] [PubMed]

13. Voutsadakis, I.A. The network of pluripotency, epithelial-mesenchymal transition, and prognosis of breast cancer. Breast Cancer 2015, 7, 303-319. [CrossRef] [PubMed]

14. Moreno-Bueno, G.; Cubillo, E.; Sarrió, D.; Peinado, H.; Rodríguez-Pinilla, S.M.; Villa, S.; Bolós, V.; Jordá, M.; Fabra, A.; Portillo, F.; et al. Genetic profiling of epithelial cells expressing E-Cadherin repressors reveals a distinct role for Snail, Slug, and E47 factors in Epithelial-Mesenchymal Transition. Cancer Res. 2006, 66, 9543-9556. [CrossRef] [PubMed]

15. Tran, D.D.; Corsa, C.A.S.; Biswas, H.; Aft, R.L. Longmore GD. Temporal and spatial cooperation of Snail1 and Twist1 during Epithelial-Mesenchymal Transition predicts for human breast cancer recurrence. Mol. Cancer Res. 2011, 9, 1644-1657. [CrossRef] [PubMed]

16. De Herreros, A.G.; Peiró, S.; Nassour, M.; Savagner, P. Snail family regulation and epithelial mesenchymal transitions in breast cancer progression. J. Mammary Gland Biol. Neoplasia 2010, 15, 135-147. [CrossRef] [PubMed]

17. Proia, T.A.; Keller, P.J.; Gupta, P.B.; Klebba, I.; Jones, A.D.; Sedic, M.; Gilmore, H.; Tung, N.; Naber, S.P.; Schnitt, S.; et al. Genetic predisposition directs breast cancer phenotype by dictating progenitor cell fate. Cell Stem Cell 2011, 8, 149-163. [CrossRef] [PubMed]

18. Mitre-Aguilar, I.B.; Cabrera-Quintero, A.J.; Zentella-Dehesa, A. Genomic and non-genomic effects of glucocorticoids: Implications for breast cancer. Int. J. Clin. Exp. Pathol. 2015, 8, 1-10. [PubMed]

19. Denayer, S.; Helsen, C.; Thorrez, L.; Haelens, A.; Claessens, F. The rules of DNA recognition by the Androgen Receptor. Mol. Endocrinol. 2010, 24, 898-913. [CrossRef] [PubMed]

20. Zhao, C.; Dahlman-Wright, K.; Gustafsson, J.-Å. Estrogen signalling via Estrogen Receptor $\beta$. J. Biol. Chem. 2010, 285, 39575-39579. [CrossRef] [PubMed]

21. Ratman, D.; Vande Berghe, W.; Dejager, L.; Libert, C.; Tavernier, J.; Beck, I.M.; de Bosscher, K. How glucocorticoid receptors modulate the activity of other transcription factors: A scope beyond tethering. Mol. Cell. Endocrinol. 2013, 380, 41-54. [CrossRef] [PubMed]

22. Lupien, M.; Brown, M. Cistromics of hormone-dependent cancer. Endocr. Relat. Cancer 2009, 16, 381-389. [CrossRef] [PubMed]

23. Horwitz, K.B.; Dye, W.W.; Chuck Harrell, J.; Kabos, P.; Sartorius, C.A. Rare steroid receptor-negative basal-like tumorigenic cells in luminal subtype human breast cancer xenografts. Proc. Natl. Acad. Sci. USA 2008, 105, 5774-5779. [CrossRef] [PubMed]

24. Kabos, P.; Haughian, J.M.; Wang, X.; Dye, W.W.; Finlayson, C.; Elias, A.; Horwitz, K.B.; Sartorius, C.A. Cytokeratin 5 positive cells represent a steroid receptor negative and therapy resistant subpopulation in luminal breast cancers. Breast Cancer Res. Treat. 2011, 128, 45-55. [CrossRef] [PubMed]

25. Harrison, H.; Simões, B.M.; Rogerson, L.; Howell, S.J.; Landberg, G.; Clarke, R.B. Oestrogen increases the activity of oestrogen receptor negative breast cancer stem cells through paracrine EGFR and Notch signalling. Breast Cancer Res. 2013, 15, R21. [CrossRef] [PubMed]

26. Hong, S.H.; Nah, H.Y.; Lee, Y.J.; Lee, J.W.; Park, J.H.; Kim, S.J.; Lee, J.B.; Yoon, H.S.; Kim, C.H. Expression of Estrogen Receptor- $\alpha$ and $-\beta$, Glucocorticoid Receptor, and Progesterone Receptor genes in human embryonic stem cells and embryoid bodies. Mol. Cells 2005, 18, 320-325.

27. Guttilla, I.K.; Adams, B.D.; White, B.A. ER $\alpha$, microRNAs, and the epithelial-mesenchymal transition in breast cancer. Trends Endocrinol. Metable 2012, 23, 73-82. [CrossRef] [PubMed] 
28. Al Saleh, S.; Al Mulla, F.; Luqmani, Y.A. Estrogen Receptor silencing induces Epithelial to Mesenchymal Transition in human breast cancer cells. PLoS ONE 2011, 6, e20610. [CrossRef] [PubMed]

29. Bouris, P.; Skandalis, S.S.; Piperigkou, Z.; Afratis, N.; Karamanou, K.; Aletras, A.J.; Moustakas, A.; Theocharis, A.D.; Karamanos, N.K. Estrogen receptor alpha mediates epithelial to mesenchymal transition, expression of specific matrix effectors and functional properties of breast cancer cells. Matrix Biol. 2015, 43, 42-60. [CrossRef] [PubMed]

30. Ito, I.; Hanyu, A.; Wayama, M.; Goto, N.; Katsuno, Y.; Kawasaki, S.; Nakajima, Y.; Kajiro, M.; Komatsu, Y.; Fujimura, A.; et al. Estrogen inhibits Transforming Growth Factor $\beta$ signalling by promoting Smad2/3 degradation. J. Biol. Chem. 2010, 285, 14747-14755. [CrossRef] [PubMed]

31. Grimm, S.L.; Rosen, J.M. Stop! In the name of transforming growth factor- $\beta$; keeping estrogen receptor- $\alpha$-positive mammary epithelial cells from proliferating. Breast Cancer Res. 2006, 8, 106. [CrossRef] [PubMed]

32. Wang, X.; Belguise, K.; Kersual, N.; Kirsch, K.H.; Mineva, N.D.; Galtier, F.; Chalbos, D.; Sonenshein, G.E. Oestrogen signalling inhibits invasive phenotype by repressing RelB and its target BCL2. Nat. Cell Biol. 2007, 9, 470-478. [CrossRef] [PubMed]

33. Wang, X.; Belguise, K.; O’Neill, C.F.; Sánchez-Morgan, N.; Romagnoli, M.; Eddy, S.F.; Mineva, N.D.; Yu, Z.; Min, C.; Trinkaus-Randall, V.; et al. RelB NF-кB represses Estrogen Receptor $\alpha$ expression via induction of the zinc finger protein Blimp1. Mol. Cell. Biol. 2009, 29, 3832-3844. [CrossRef] [PubMed]

34. Guo, S.; Li, Y.; Tong, Q.; Gu, F.; Zhu, T.; Fu, L.; Yang, S. $\delta E F 1$ down-regulates ER- $\alpha$ expression and confers tamoxifen resistance in breast cancer. PLoS ONE 2012, 7, e52380. [CrossRef] [PubMed]

35. Scherbakov, A.M.; Andreeva, O.E.; Shatskaya, V.A.; Krasil'nikov, M.A. The relationships between Snail1 and estrogen receptor signalling in breast cancer cells. J. Cell. Biochem. 2012, 113, 2147-2155. [CrossRef] [PubMed]

36. Mishra, S.K.; Talukder, A.H.; Gururaj, A.E.; Yang, Z.; Singh, R.R.; Mahoney, M.G.; Franci, C.; Vadlamudi, R.K.; Kumar, R. Upstream determinants of Estrogen Receptor- $\alpha$ regulation of Metastatic Tumor Antigen 3 pathway. J. Biol. Chem. 2004, 279, 32709-32715. [CrossRef] [PubMed]

37. Haldosén, L.-A.; Zhao, C.; Dahlman-Wright, K. Estrogen receptor beta in breast cancer. Mol. Cell. Endocrinol. 2014, 382, 665-672. [CrossRef] [PubMed]

38. Speirs, V.; Skliris, G.P.; Burdall, S.E.; Carder, P.J. Distinct expression patterns of ER alpha and ER beta in normal human mammary gland. J. Clin. Pathol. 2002, 55, 371-374. [CrossRef] [PubMed]

39. Fox, E.M.; Davis, R.J.; Shupnik, M.A. ER $\beta$ in breast cancer- Onlooker, passive player, or active protector? Steroids 2008, 73, 1039-1051. [CrossRef] [PubMed]

40. Guo, L.; Meng, J.; Yilamu, D.; Jakulin, A.; Fu, M.; Wang, B.; Abulajiang, G. Significance of ER $\beta$ expression in different molecular subtypes of breast cancer. Diagn. Pathol. 2014, 9, 20. [CrossRef] [PubMed]

41. Reese, J.M.; Suman, V.J.; Subramaniam, M.; Wu, X.; Negron, V.; Gingery, A.; Pitel, K.S.; Shah, S.S.; Cunliffe, H.E.; McCullough, A.E.; et al. ER $\beta 1$ : Characterization, prognosis, and evaluation of treatment strategies in ER $\alpha$-positive and -negative cancer. BMC Cancer 2014, 14, 749. [CrossRef] [PubMed]

42. Chang, E.C.; Frasor, J.; Komm, B.; Katzenellenbogen, B.S. Impact of Estrogen Receptor $\beta$ on gene networks regulated by Estrogen Receptor $\alpha$ in breast cancer cells. Endocrinology 2006, 147, 4831-4842. [CrossRef] [PubMed]

43. Williams, C.; Edvardsson, K.; Lewandowski, S.A.; Ström, A.; Gustafsson, J.-Å. A genome-wide study of the repressive effects of estrogen receptor beta on estrogen receptor alpha signaling in breast cancer cells. Oncogene 2008, 27, 1019-1032. [CrossRef] [PubMed]

44. Hefti, M.M.; Hu, R.; Knoblauch, N.W.; Collins, L.C.; Haibe-Kains, B.; Tamimi, R.M.; Beck, A.H. Estrogen receptor negative/progesterone receptor positive breast cancer is not a reproducible subtype. Breast Cancer Res. 2013, 15, R68. [CrossRef] [PubMed]

45. Chlebowski, R.T.; Anderson, G.L.; Gass, M.; Lane, D.S.; Aragaki, A.K.; Kuller, L.H.; Manson, J.E.; Stefanick, M.L.; Ockene, J.; Sarto, G.E.; et al. Estrogen plus progestin and breast cancer incidence and mortality in postmenopausal women. JAMA 2010, 304, 1684-1692. [CrossRef] [PubMed]

46. Cancello, G.; Maisonneuve, P.; Rotmensz, N.; Viale, G.; Mastropasqua, M.G.; Pruneri, G.; Montagna, E.; Iorfida, M.; Mazza, M.; Balduzzi, A.; et al. Progesterone receptor loss identifies luminal B breast cancer subgroups at higher risk of relapse. Ann. Oncol. 2013, 24, 661-668. [CrossRef] [PubMed]

47. Diep, C.H.; Daniel, A.R.; Mauro, L.J.; Knutson, T.P.; Lange, C.A. Progesterone action in breast, uterine, and ovarian cancers. J. Mol. Endocrinol. 2015, 54, R31-R53. [CrossRef] [PubMed] 
48. Chen, C.-C.; Hardy, D.B.; Mendelson, C.R. Progesterone Receptor inhibits proliferation of human breast cancer cells via induction of MAPK Phosphatase 1 (MKP-1/DUSP1). J. Biol. Chem. 2011, 286, 43091-43102. [CrossRef] [PubMed]

49. Knutson, T.P.; Lange, C.A. Tracking progesterone receptor-mediated actions in breast cancer. Pharmacol. Ther. 2014, 142, 114-125. [CrossRef] [PubMed]

50. Nguyen, D.H.; Parlow, A.F.; Neville, M.C. Hormonal regulation of tight junction closure in the mouse mammary epithelium during the transition from pregnancy to lactation. J. Endocrinol. 2001, 170, 347-356. [CrossRef]

51. Obr, A.E.; Edwards, D.P. The biology of progesterone receptor in the normal mammary gland and in breast cancer. Mol. Cell. Endocrinol. 2012, 357, 4-17. [CrossRef] [PubMed]

52. Brisken, C.; Heineman, A.; Chavarria, T.; Elenbaas, B.; Tan, J.; Dey, S.K.; McMahon, J.A.; McMahon, A.P.; Weinberg, R.A. Essential function of Wnt-4 in mammary gland development downstream of progesterone signaling. Genes Dev. 2000, 14, 650-654. [PubMed]

53. Fernandez-Valdivia, R.; Mukherjee, A.; Creighton, C.J.; Buser, A.C.; DeMayo, F.J.; Edwards, D.P.; Lydon, J.P. Transcriptional response of the murine mammary gland to acute progesterone exposure. Endocrinology 2008, 149, 6236-6250. [CrossRef] [PubMed]

54. Fernandez-Valdivia, R.; Mukherjee, A.; Ying, Y.; Li, J.; Paquet, M.; DeMayo, F.J.; Lydon, J.P. The RANKL signaling axis is sufficient to elicit ductal side-branching and alveologenesis in the mammary gland of the virgin mouse. Dev. Biol. 2009, 328, 127-139. [CrossRef] [PubMed]

55. Kariagina, A.; Xie, J.; Langohr, I.M.; Opreanu, R.C.; Basson, M.D.; Haslam, S.Z. Progesterone decreases levels of the adhesion protein E-cadherin and promotes invasiveness of steroid receptor positive breast cancers. Horm. Cancer 2013, 4, 381-390.

56. Conneely, O.M.; Mulac-Jericevic, B.; Lydon, J.P. Progesterone-dependent regulation of female reproductive activity by two distinct progesterone receptor isoforms. Steroids 2003, 68, 771-778. [CrossRef]

57. Pistelli, M.; Caramanti, M.; Biscotti, T.; Santinelli, A.; Pagliacci, A.; de Lisa, M.; Ballatore, Z.; Ridolfi, F.; Maccaroni, E.; Bracci, R.; et al. Androgen Receptor expression in early triple-negative breast cancer: Clinical significance and prognostic associations. Cancers 2014, 6, 1351-1362. [CrossRef] [PubMed]

58. Tsutsumi, Y. Apocrine carcinoma as triple-negative breast cancer: Novel definition of apocrine-type carcinoma as Estrogen/Progesterone Receptor-negative and Androgen Receptor-positive invasive ductal carcinoma. Jpn. J. Clin. Oncol. 2012, 42, 375-386. [CrossRef] [PubMed]

59. Park, S.; Koo, J.; Park, H.S.; Kim, J.H.; Choi, S.Y.; Lee, J.H.; Park, B.W.; Lee, K.S. Expression of androgen receptors in primary breast cancer. Ann. Oncol. 2010, 21, 488-492. [CrossRef] [PubMed]

60. Vera-Badillo, F.E.; Templeton, A.J.; de Gouveia, P.; Diaz-Padilla, I.; Bedard, P.L.; Al-Mubarak, M.; Seruga, B.; Tannock, I.F.; Ocana, A.; Amir, E. Androgen Receptor expression and outcomes in early breast cancer: A systematic review and meta-analysis. J. Natl. Cancer Inst. 2014, 106, 1-11. [CrossRef] [PubMed]

61. Liu, Y.-N.; Lee, H.-J.; Hsu, Y.-H.; Chen, J.-H. Activated Androgen Receptor downregulates E-cadherin gene expression and promotes tumor metastasis. Mol. Cell. Biol. 2008, 28, 7096-7108. [CrossRef] [PubMed]

62. Voutsadakis, I.A.; Papandreou, C.N. The ubiquitin-proteasome system in prostate cancer and its transition to castration resistance. Urol. Oncol. 2012, 30, 752-761. [CrossRef] [PubMed]

63. Hundertmark, S.; Buhler, H.; Rudolf, M.; Weitzel, H.K.; Ragosch, V. Inhibition of 11 beta-hydroxysteroid gehydrogenase activity enhances the antiproliferative effect of glucocorticosteroids on MCF-7 and ZR-75-1 breast cancer cells. J. Endocrinol. 1997, 155, 171-180. [CrossRef] [PubMed]

64. Aziz, M.H.; Shen, H.; Maki, C.G. Glucocorticoid receptor activation inhibits p53-induced apoptosis of MCF10Amyc cells via induction of protein kinase Ce. J. Biol. Chem. 2012, 287, 29825-29836. [CrossRef] [PubMed]

65. Abduljabbar, R.; Negm, O.H.; Lai, C.F.; Jerjees, D.A.; Al-Kaabi, M.; Hamed, M.R.; Tighe, P.J.; Buluwela, L.; Mukherjee, A.; Green, A.R.; et al. Clinical and biological significance of glucocorticoid receptor (GR) expression in breast cancer. Breast Cancer Res. Treat. 2015, 150, 335-346. [CrossRef] [PubMed]

66. Buxant, F.; Engohan-Aloghe, C.; Noël, J.-C. Estrogen Receptor, Progesterone Receptor, and Glucoccorticoid Receptor expression in normal breast tissue, breast in situ carcinoma, and invasive breast cancer. Appl. Immunohistochem. Mol. Morphol. 2010, 18, 254-257. [CrossRef] [PubMed]

67. Vilasco, M.; Communal, L.; Mourra, N.; Courtin, A.; Forgez, P.; Gompel, A. Glucocorticoid receptor and breast cancer. Breast Cancer Res. Treat. 2011, 130, 1-10. [CrossRef] [PubMed] 
68. Karmakar, S.; Jin, Y.; Nagaich, A.K. Interaction of Glucoccorticoid Receptor (GR) with Estrogen Receptor (ER) $\alpha$ and Activator Protein 1 (AP1) in dexamethasone-mediated interference of ER $\alpha$ activity. J. Biol. Chem. 2013, 288, 24020-24034. [CrossRef] [PubMed]

69. Bolt, M.J.; Stossi, F.; Newberg, J.Y.; Orjalo, A.; Johansson, H.E.; Mancini, M.A. Coactivators enable glucocorticoid receptor recruitment to fine-tune estrogen receptor transcriptional responses. Nucleic Acids Res. 2013, 41, 4036-4048. [CrossRef] [PubMed]

70. Miranda, T.B.; Voss, T.C.; Sung, M.-H.; Baek, S.; John, S.; Hawkins, M.; Grøntved, L.; Schiltz, R.L.; Hager, G.L. Reprogramming the chromatin landscape: Interplay of the estrogen and glucocorticoid receptors at the genomic level. Cancer Res. 2013, 73, 5130-5139. [CrossRef] [PubMed]

71. Vilasco, M.; Communal, L.; Hugon-Rodin, J.; Penault-Llorca, F.; Mourra, N.; Wu, Z.; Forgez, P.; Gompel, A.; BRACAPS. Loss of glucocorticoid receptor activation is a hallmark of BRCA1-mutated breast tissue. Breast Cancer Res. Treat. 2013, 142, 283-296. [CrossRef] [PubMed]

72. Bai, F.; Chan, H.L.; Scott, A.; Smith, M.D.; Fan, C.; Herschkowitz, J.I.; Perou, C.M.; Livingstone, A.S.; Robbins, D.J.; Capobianco, A.J.; et al. BRCA1 suppresses epithelial-to-mesenchymal transition and stem cell dedifferentiation during mammary and tumor development. Cancer Res. 2014, 74, 6161-6172. [CrossRef] [PubMed]

73. Lindeman, G.L.; Visvader, J.E. Cell fate takes a slug in BRCA1-associated breast cancer. Breast Cancer Res. 2011, 13, 306. [CrossRef] [PubMed]

74. Pan, D.; Kocherginsky, M.; Conzen, S.D. Activation of the Glucocorticoid Receptor is associated with poor prognosis in Estrogen Receptor-negative breast cancer. Cancer Res. 2011, 71, 6360-6370. [CrossRef] [PubMed]

75. Wyszomierski, S.L.; Rosen, J.M. Cooperative effects of STAT5 (signal transducer and activator of transcription 5) and C/EBPbeta (CCAAT/ Enhancer-binding protein-beta) on beta-casein gene transcription are mediated by the glucocorticoid receptor. Mol. Endocrinol. 2001, 15, 228-240. [PubMed]

76. Leo, J.C.L.; Guo, C.; Woon, C.T.; Aw, S.E.; Lin, V.C.L. Glucocorticoid and Mineralocorticoid cross-talk with Progesterone Receptor to induce focal adhesion and growth inhibition in breast cancer cells. Endocrinology 2004, 145, 1314-1321. [CrossRef] [PubMed]

77. Lehmann, B.D.; Bauer, J.A.; Chen, X.; Sanders, M.E.; Chakravarthy, A.B.; Shyr, Y.; Pietenpol, J.A. Identification of human triple-negative breast cancer subtypes and preclinical models for selection of targeted therapies. J. Clin. Investig. 2011, 121, 2750-2767. [CrossRef] [PubMed]

78. Skor, M.N.; Wonder, E.L.; Kocherginsky, M.; Goyal, A.; Hall, B.A.; Cai, Y.; Conzen, S.D. Glucocorticoid Receptor antagonism as a novel therapy for triple-negative breast cancer. Clin. Cancer Res. 2013, 19, 6163-6172. [CrossRef] [PubMed]

79. García de Herreros, A.; Baulida, J. Cooperation, amplification, and feed-back in epithelial-mesenchymal transition. Biochim. Biophys. Acta 2012, 1825, 223-228.

80. Kingsley-Kallesen, M.; Mukhopadhyay, S.S.; Wyszomierski, S.L.; Schanler, S.; Schutz, G.; Rosen, J.M. The mineralocorticoid receptor may compensate for the loss of the glucocorticoid receptor at specific stages of mammary gland development. Mol. Endocrinol. 2002, 16, 2008-2018. [CrossRef] [PubMed]

81. Diah, S.; Zhang, G.-X.; Nagai, Y.; Zhang, W.; Gang, L.; Kimura, S.; Abdul Hamid, M.R.W.; Tamiya, T.; Nishiyama, A.; Hitomi, H. Aldosterone induces myofibroblastic transdifferentiation and collagen gene expression through the Rho-kinase dependent signaling pathway in rat mesangial cells. Exp. Cell Res. 2008, 314, 3654-3662. [CrossRef] [PubMed]

82. Zhang, A.; Jia, Z.; Guo, X.; Yang, T. Aldosterone induces epithelial-mesenchymal transition via ROS of mitochondrial origin. Am. J. Physiol. Renal Physiol. 2007, 293, F723-F731. [CrossRef] [PubMed]

83. Foubert, E.; De Craene, B.; Berx, G. Key signaling nodes in mammary gland development and cancer. The Snail1-Twist1 conspiracy in malignant breast cancer progression. Breast Cancer Res. 2010, 12, 206. [CrossRef] [PubMed]

84. Lee, K.A.; Gjorevski, N.; Boghaert, E.; Radisky, D.C.; Nelson, C.M. Snail1, Snail2, and E47 promote mammary epithelial branching morphogenesis. EMBO J. 2011, 30, 2662-2674. [CrossRef] [PubMed]

85. Gras, B.; Jacqueroud, L.; Wierinckx, A.; Lamblot, C.; Fauvet, F.; Lachuer, J.; Puisieux, A.; Ansieau, S. Snail family members unequally trigger EMT and thereby differ in their ability to promote the neoplastic transformation of mammary epithelial cells. PLoS ONE 2014, 9, e92254. [CrossRef] [PubMed] 
86. Zhang, A.; Wang, Q.; Han, Z.; Hu, W.; Xi, L.; Gao, Q.; Wang, S.; Zhou, J.; Xu, G.; Meng, L.; et al. Reduced expression of Snail decreases breast cancer cell motility by downregulating the expression and inhibiting the activity of RhoA GTPase. Oncol. Lett. 2013, 6, 339-346. [PubMed]

87. Okubo, T.; Truong, T.K.; Yu, B.; Itoh, T.; Zhao, J.; Grube, B.; Zhou, D.; Chen, S. Down-regulation of promoter I.3 activity of the human aromatase gene in breast tissue by zinc-finger protein, Snail (SnaH). Cancer Res. 2001, 61, 1338-1346. [PubMed]

88. Martin, T.A.; Goyal, A.; Watkins, G.; Jiang, W.G. Expression of the transcription factor Snail, Slug, and Twist and their clinical significance in human breast cancer. Ann. Surg. Oncol. 2005, 12, 1-9. [CrossRef] [PubMed]

89. Ye, Y.; Wang, W.; Yearsley, K.; Gao, J.-X.; Barsky, S.H. ER $\alpha$ suppresses slug expression directly by translational repression. Biochem. J. 2008, 416, 179-187. [CrossRef] [PubMed]

90. Ye, Y.; Xiao, Y.; Wang, W.; Yearsley, K.; Gao, J.-X.; Shetuni, B.; Barsky, S.H. ER $\alpha$ signalling through slug regulates E-cadherin and EMT. Oncogene 2010, 29, 1451-1462. [CrossRef] [PubMed]

91. Fujita, N.; Jaye, D.L.; Kajita, M.; Gelgerman, C.; Moreno, C.S.; Wade, P.A. MTA3, a Mi-2/NuRD complex subunit, regulates an invasive growth pathway in breast cancer. Cell 2003, 113, 207-219. [CrossRef]

92. Wang, M.; Zhao, F.; Li, S.; Chang, A.K.; Jia, Z.; Chen, Y.; Xu, F.; Pan, H.; Wu, H. AIB1 cooperates with ER $\alpha$ to promote epithelial mesenchymal transition in breast cancer through SNAI1 activation. PLoS ONE 2013,8, e65556. [CrossRef] [PubMed]

93. Chimge, N.-O.; Baniwal, S.K.; Little, G.H.; Chen, Y.; Kahn, M.; Tripathy, D.; Borok, Z.; Frenkel, B. Regulation of breast cancer metastasis by Runx2 and estrogen signalling: The role of SNAI2. Breast Cancer Res. 2011, 13, R127. [CrossRef] [PubMed]

94. Lu, T.; Lin, W.-J.; Izumi, K.; Wang, X.; Xu, D.; Fang, L.-Y.; Li, L.; Jiang, Q.; Jin, J.; Chang, C. Targeting Androgen Receptor to suppress macrophage-induced EMT and benign prostatic hyperplasia (BPH) development. Mol. Endocrinol. 2012, 26, 1707-1715.

95. Wu, K.; Gore, C.; Yang, L.; Fazli, L.; Gleave, M.; Pong, R.-C.; Xiao, G.; Zhang, L.; Yun, E.-J.; Tseng, S.-F.; et al. Slug, a unique Androgen-regulated transcription factor, coordinates Androgen Receptor to facilitate castration resistance in prostate cancer. Mol. Endocrinol. 2012, 26, 1496-1507. [CrossRef] [PubMed]

96. Chang, C.; Lee, S.O.; Yeh, S.; Chang, T.M. Androgen receptor (AR) differential roles in hormone-related tumors including prostate, bladder, kidney, lung, breast and liver. Oncogene 2014, 33, 3225-3234. [CrossRef] [PubMed]

97. Stender, J.D.; Kim, K.; Charn, T.H.; Komm, B.; Chang, K.C.N.; Kraus, W.L.; Benner, C.; Glass, C.K.; Katzenellenbogen, B.S. Genome-wide analysis of Estrogen Receptor $\alpha$ DNA binding and tethering mechanisms identifies Runx1 as a novel tethering factor in receptor-mediated transcriptional activation. Mol. Cell. Biol. 2010, 30, 3943-3955. [CrossRef] [PubMed]

98. Hill, L.; Browne, G.; Tulchinsky, E. ZEB/miR-200 feedback loop: At the crossroads of signal transduction in cancer. Int. J. Cancer 2013, 132, 745-754. [CrossRef] [PubMed]

99. Hurteau, G.J.; Carlson, J.A.; Spivack, S.D.; Brock, G.J. Overexpression of the MicroRNA has-miR-200c leads to reduced expression of transcription factor 8 and increased expression of E-cadherin. Cancer Res. 2007, 67, 7972-7976. [CrossRef] [PubMed]

100. Feng, X.; Wang, Z.; Filmore, R.; Xi, Y. miR-200, a new star miRNA in human cancer. Cancer Lett. 2014, 344, 166-173. [CrossRef] [PubMed]

101. Hilmarsdottir, B.; Briem, E.; Bergthorsson, J.T.; Magnusson, M.K.; Gudjonsson, T. Functional role of the microRNA-200 family in breast morphogenesis and neoplasia. Genes 2014, 5, 804-820. [CrossRef] [PubMed]

102. Bracken, C.P.; Li, X.; Wright, J.A.; Lawrence, D.M.; Pillman, K.A.; Salmanidis, M.; Anderson, M.A.; Dredge, B.K.; Gregory, P.A.; Tsykin, A.; et al. Genome-wide identification of miR-200 targets reveals a regulatory network controlling cell invasion. EMBO J. 2014, 33, 2040-2056. [CrossRef] [PubMed]

103. Brabletz, S.; Brabletz, T. The ZEB/ miR-200 feedback loop- a motor of cellular plasticity in development and cancer? EMBO Rep. 2010, 11, 670-677. [CrossRef] [PubMed]

104. Chamberlain, E.M.; Sanders, M.M. Identification of the novel player $\delta E F 1$ in estrogen transcriptional cascades. Mol. Cell. Biol. 1999, 19, 3600-3606. [CrossRef] [PubMed]

105. Spoeltra, N.S.; Manning, N.G.; Higashi, Y.; Darling, D.; Singh, M.; Shroyer, K.R.; Broaddus, R.R.; Horwitz, K.B.; Richer, J.K. The transcription factor ZEB1 is aberrantly expressed in aggressive uterine cancers. Cancer Res. 2006, 66, 3893-3902. [CrossRef] [PubMed] 
106. Hurt, E.M.; Saykally, J.N.; Anose, B.M.; Kalli, K.R.; Sanders, M.M. Expression of the ZEB1 ( $\delta E F 1)$ transcription factor in human: Additional insights. Mol. Cell. Biochem. 2008, 318, 89-99. [CrossRef] [PubMed]

107. Tuomarila, M.; Luostari, K.; Soini, Y.; Kataja, V.; Kosma, V.-M.; Mannermaa, A. Overexpression of micro-RNA-200c predicts poor outcome in patients with PR-negative breast cancer. PLoS ONE 2014, 9, e109508. [CrossRef] [PubMed]

108. Manavalan, T.T.; Teng, Y.; Litchfield, L.M.; Muluhngwi, P.; Al-Rayyan, N.; Klinge, C.M. Reduced expression of miR-200 family members contributes to antiestrogen resistance in LY2 human breast cancer cells. PLoS ONE 2013, 8, e62334. [CrossRef] [PubMed]

109. Richer, J.K.; Jacobsen, B.M.; Manning, N.G.; Abel, M.G.; Wolf, D.M.; Horwitz, K.B. Differential gene regulation by the two progesterone receptor isoforms in human breast cancer cells. J. Biol. Chem. 2002, 277, 5209-5218. [CrossRef] [PubMed]

110. Anose, B.M.; Sanders, M.M. Androgen receptor regulates transcription of the ZEB1 transcription factor. Int. J. Endocrinol. 2011, 2011, 903918. [CrossRef] [PubMed]

111. Graham, T.R.; Yacoub, R.; Taliaferro-Smith, L.; Osunkoya, A.O.; Odero-Marah, V.A.; Liu, T.; Kimbro, K.S.; Sharma, D.; O'Reagan, R.M. Reciprocal regulation of ZEB1 and AR in triple negative breast cancer cells. Breast Cancer Res. Treat. 2010, 123, 139-147. [CrossRef] [PubMed]

112. Kasimir-Bauer, S.; Hoffmann, O.; Wallwiener, D.; Kimmig, R.; Fehm, T. Expression of stem cell and epithelial-mesenchymal transition markers in primary breast cancer patients with circulating tumor cells. Breast Cancer Res. 2012, 14, R15. [CrossRef] [PubMed]

113. Van Nes, J.G.; de Kruijf, E.M.; Putter, H.; Faratian, D.; Munro, A.; Campbell, F.; Smit, V.T.H.B.M.; Liefers, G.-J.; Kuppen, P.J.K; van de Velde, C.J.H.; et al. Co-expression of SNAIL and TWIST determines prognosis in estrogen receptor-positive early breast cancer patients. Breast Cancer Res Treat. 2012, 133, 49-59. [CrossRef] [PubMed]

114. Tilghman, S.L.; Townley, I.; Zhong, Q.; Carriere, P.P.; Zou, J.; Llopis, S.D.; Preyan, L.C.; Williams, C.C.; Skripnikova, E.; Bratton, M.R.; et al. Proteomic signatures of acquired letrozole resistance in breast cancer: Suppresssed estrogen signalling and increased cell motility and invasiveness. Mol. Cell. Proteom. 2013, 12, 2440-2455. [CrossRef] [PubMed]

115. Vesuna, F.; Lisok, A.; Kimble, B.; Domek, J.; Kato, Y.; van der Groep, P.; Artemov, D.; Kowalski, J.; Carraway, H.; van Diest, P.; et al. Twist contributes to hormone resistance in breast cancer by down-regulating estrogen receptor alpha. Oncogene 2012, 31, 3223-3234. [CrossRef] [PubMed]

116. Fu, J.; Zhang, L.; He, T.; Xiao, X.; Liu, X; Wang, L.; Yang, L.; Yang, M.; Zhang, T.; Chen, R.; et al. TWIST represses Estrogen Receptor-alpha expression by recruiting the NuRD protein complex in breast cancer cells. Int. J. Biol. Sci. 2012, 8, 522-532. [CrossRef] [PubMed]

117. Lapidus, R.G.; Ferguson, A.T.; Ottaviano, Y.L.; Parl, F.F.; Smith, H.S.; Weitzman, S.A.; Baylin, S.B.; Issa, J.P.; Davidson, N.E. Methylation of estrogen receptor gene 5' CpG islands correlates with lack of estrogen and progesterone receptor gene expression in breast tumors. Clin. Cancer Res. 1996, 2, 805-810. [PubMed]

118. Cubillo, E.; Diaz-Lopez, A.; Cuevas, E.P.; Moreno-Bueno, G.; Peinado, H.; Montes, A.; Santos, V.; Portillo, F.; Cano, A. E47 and Id1 interplay in epithelial-mesenchymal transition. PLoS ONE 2013, 8, e59948. [CrossRef] [PubMed]

119. Perk, J.; Gil-Bazo, I.; Chin, Y.; de Candia, P.; Chen, J.J.; Zhao, Y.; Chao, S.; Cheong, W.; Ke, Y.; Al-Ahmadie, H.; et al. Reassessement of Id1 protein expression in human mammary, prostate, and bladder cancers using a monospecific rabbit monoclonal anti-id1 antibody. Cancer Res. 2006, 66, 10870-10877. [CrossRef] [PubMed]

120. Mani, S.A.; Yang, J.; Brooks, M.; Schwaninger, G.; Zhou, A.; Miura, N.; Kutok, J.L.; Hartwell, K.; Richardson, A.L.; Weinberg, R.A. Mesenchyme Forkhead 1 (FOXC2) plays a key role in metastasis and is associated with aggressive basal-like breast cancers. Proc. Natl. Acad. Sci. USA 2007, 104, 10069-10074. [CrossRef] [PubMed]

121. Bard, J.B.L.; Lam, M.S.; Aitken, S. A bioinformatics approach for identifying candidate transcriptional regulators of Mesenchyme-to-Epithelium Transitions in mouse embryos. Dev. Dyn. 2008, 237, 2748-2754. [CrossRef] [PubMed]

122. Hader, C.; Marlier, A.; Cantley, L. Mesenchymal-epithelial transition in epithelial response to injury: The role of Foxc2. Oncogene 2010, 29, 1031-1040. [CrossRef] [PubMed] 
123. Grønning, L.M.; Cederberg, A.; Miura, N.; Evenbäck, S.; Taskén, K. Insulin and TNF $\alpha$ induce expression of the Forkhead transcription factor gene Foxc2 in 3T3-L1 adipocytes via PI3K and ERK 1/2-dependent pathways. Mol. Endocrinol. 2002, 16, 873-883. [PubMed]

124. Golden, D.; Cantley, L.G. Casen kinase 2 prevents mesenchymal transformation by maintaining Foxc2 in the cytoplasm. Oncogene 2015, 34, 4702-4712. [CrossRef] [PubMed]

125. Hollier, B.G.; Tinnirello, A.A.; Werden, S.J.; Evans, K.W.; Taube, J.H.; Roy Sarkar, T.; Sphyris, N.; Shariati, M.; Kumar, S.V.; Battula, V.L.; et al. FOXC2 expression links Epithelial-Mesenchymal Transition and stem cell properties in breast cancer. Cancer Res. 2012, 73, 1981-1992. [CrossRef] [PubMed]

126. Hartwell, K.A.; Muir, B.; Reinhardt, F.; Carpenter, A.E.; Sgroi, D.C.; Weinberg, R.A. The Spemann organizer gene, Goosecoid, promotes tumor metastasis. Proc. Natl. Acad. Sci. USA 2006, 103, 18969-18974. [CrossRef] [PubMed]

127. Watabe, T.; Kim, S.; Candia, A.; Rothbächer, U.; Hashimoto, C.; Inoue, K.; Cho, K.W.Y. Molecular mechanisms of Spemann's organizer formation: Conserved growth factor synergy between Xenopus and mouse. Genes Dev. 1995, 9, 3038-3050. [CrossRef] [PubMed]

128. Xue, T.-C.; Ge, N.-L.; Zhang, L.; Cui, J.-F.; Chen, R.-X.; You, Y.; Ye, S.-L.; Ren, Z.-G. Goosecoid promotes the metastasis of hepatocellular carcinoma by modulating the epithelial-mesenchymal transition. PLoS ONE 2014, 9, e109695. [CrossRef] [PubMed]

129. Ell, B.; Kang, Y. Transcriptional control of cancer metastasis. Trends Cell Biol. 2013, 23, 603-611. [CrossRef] [PubMed]

130. Gross, M.K.; Moran-Rivard, L.; Velasquez, T.; Nakatsu, M.N.; Jagla, K.; Goulding, M. Lbx1 is required for muscle precursor migration along a lateral pathway into the limb. Development 2000, 127, 413-424. [PubMed]

131. Yu, M.; Smolen, G.A.; Zhang, J.; Wittner, B.; Schott, B.J.; Brachtel, E.; Ramaswamy, S.; Maheswaran, S.; Haber, D.A. A developmentally regulated inducer of EMT, LBX1, contributes to breast cancer progression. Genes Dev. 2009, 23, 1737-1742. [CrossRef] [PubMed]

132. Jozwik, K.M.; Carroll, J.S. Pioneer factors in hormone-dependent cancers. Nat. Rev. Cancer 2012, 12, 381-385. [CrossRef] [PubMed]

133. Carroll, J.S.; Liu, X.S.; Brodsky, A.S.; Li, W.; Meyer, C.A.; Szary, A.J.; Eeckhoute, J.; Shao, W.; Hestermann, E.V.; Geistlinger, T.R.; et al. Chromosome-wide mapping of estrogen receptor binding reveals long-range regulation requiring the forkhead protein FoxA1. Cell 2005, 122, 33-43. [CrossRef] [PubMed]

134. Robinson, J.L.; Carroll, J.S. FoxA1 is a key mediator of hormonal response in breast and prostate cancer. Front. Endocrinol. 2012, 3, 68. [CrossRef] [PubMed]

135. Robinson, J.L.L.; MacArthur, S.; Ross-Innes, C.S.; Tilley, W.D.; Neal, D.E.; Mills, I.G.; Carroll, J.S. Androgen receptor driven transcription in molecular apocrine breast cancer is mediated by FoxA1. EMBO J. 2011, 30, 3019-3027. [CrossRef] [PubMed]

136. Guiu, S.; Charon-Barra, C.; Vernerey, D.; Fumoleau, P.; Campone, M.; Spielmann, M.; Roché, H.; Mesleard, C.; Arnould, L.; Lemonnier, J.; et al. Coexpression of androgen receptor and FOXA1 in nonmetastatic triple-negative breast cancer: Ancillary study from PACS08 trial. Future Oncol. 2015, 11, 2283-2297. [CrossRef] [PubMed]

137. Liu, Y.N.; Lee, W.W.; Wang, C.Y.; Chao, T.H.; Chen, Y.; Chen, J.H. Regulatory mechanisms controlling human E-cadherin gene expression. Oncogene 2005, 24, 8277-8290. [CrossRef] [PubMed]

138. Mani, S.A.; Guo, W.; Liao, M.J.; Eaton, E.N.; Ayyanan, A.; Zhou, A.Y.; Brooks, M.; Reinhard, F.; Zhang, C.C.; Shipitsin, M.; et al. The epithelial-mesenchymal transition generates cells with properties of stem cells. Cell 2008, 133, 704-715. [CrossRef] [PubMed]

139. Preca, B.-T.; Bajdak, K.; Mock, K.; Sundararajan, V.; Pfannstiel, J.; Maurer, J.; Wellner, U.; Hopt, U.T.; Brummer, T.; Brabletz, S.; et al. A self-enforcing CD44s/ZEB1 feedback loop maintains EMT and stemness properties in cancer cells. Int. J. Cancer 2015, 137, 2566-2577. [CrossRef] [PubMed]

140. Xiao, D.; He, J. Epithelial mesenchymal transition and lung cancer. J. Thorac. Dis. 2010, 2, 154-159. [PubMed] 
141. Huang, J.; Li, H.; Ren, G. Epithelial-mesenchymal transition and drug resistance in breast cancer. Int. J. Oncol. 2015, 47, 840-848. [CrossRef] [PubMed]

142. Fischer, K.R.; Durrans, A.; Lee, S.; Sheng, J.; Li, F.; Wong, S.T.C.; Choi, H.; El Rayes, T.; Ryu, S.; Troeger, J.; et al. Epithelial-to-mesenchymal transition is not required for lung metastasis but contributes to chemoresistance. Nature 2015, 527, 472-476. [CrossRef] [PubMed]

(C) 2016 by the author; licensee MDPI, Basel, Switzerland. This article is an open access article distributed under the terms and conditions of the Creative Commons by Attribution (CC-BY) license (http://creativecommons.org/licenses/by/4.0/). 